\title{
El recurso de fuerza en los conflictos entre Felipe II y el Papado: la plenitudo quaedam iuris
}

\author{
Beatriz Cárceles de Gea *
}

\begin{abstract}
RESUMEN
ABSTRACT

La virulencia de los conflictos entre

The virulence of the conflicts

Felipe II y el Papado se explican por la between Felipe II and the Pope

necesidad que ambos tuvieron de

marcar los términos legales de la relación entre el poder espiritual y el

poder temporal. En este trabajo proponemos su estudio mediante el recurso de fuerza, instrumento legal cuyos fundamentos jurídicos llevaron a la constitución de la exención de la monarquia, y de la eventual desobediencia al Papa como un acto integrado en su orden legal. can be explained by need of both to delineate, in legal terms, the relationships among the espiritual and temporal powers. In this work we study this rapport by the recurso de fuerza, which became a legal instrument, whose juridical foundations lead to the exemption of the monarchs and the disobedience to the Pope regarded as a legal act.
\end{abstract}

En los conflictos suscitados entre Felipe II y la Santa Sede ${ }^{1}$, en la Corona de Castilla, el recurso de fuerza y la bula In coena Domini sobresalen como los dos principios nucleares de una comunicación entre sujetos jurídicos alrededor del cual se va a ir perfilando la función de ambos instru-

Université des Sciences Humaines de Strasbourg.

PhILIPPSOn, M., "Felipe II y el Pontificado", Estudios sobre Felipe II. Madrid, 1887, pp. 91160. Hinojosa Y Naveros, E., Los despachos de la diplomacia pontificia. Madrid, 1896. HeRre. P., 
mentos ${ }^{2}$. Conceptuado el recurso de fuerza a partir de la secular idea de fuerza y de defensa del súbdito ${ }^{3}$, ambos se identifican con una normativa tradicional a la que en el siglo XVI se le da un impulso y significado nuevo ${ }^{4}$. Las diferencias suscitadas con motivo de su confrontación se desenvuelven alrededor del papel desempeñado por el príncipe temporal y por el papado en sus relaciones mutuas, pero por medio de sus consiguientes relaciones y vínculos con el estado eclesiástico y el estado secular. Por tanto, este diálogo no se construye con una dualidad de tinte universalista construida sobre la base de un poder espiritual preeminente, de cuya conjunción resultaría la armonía entre la Santa Sede, como superioritas, y los estados católicos ${ }^{5}$. Al contrario, dicho diálogo debe integrarse en una comunicación

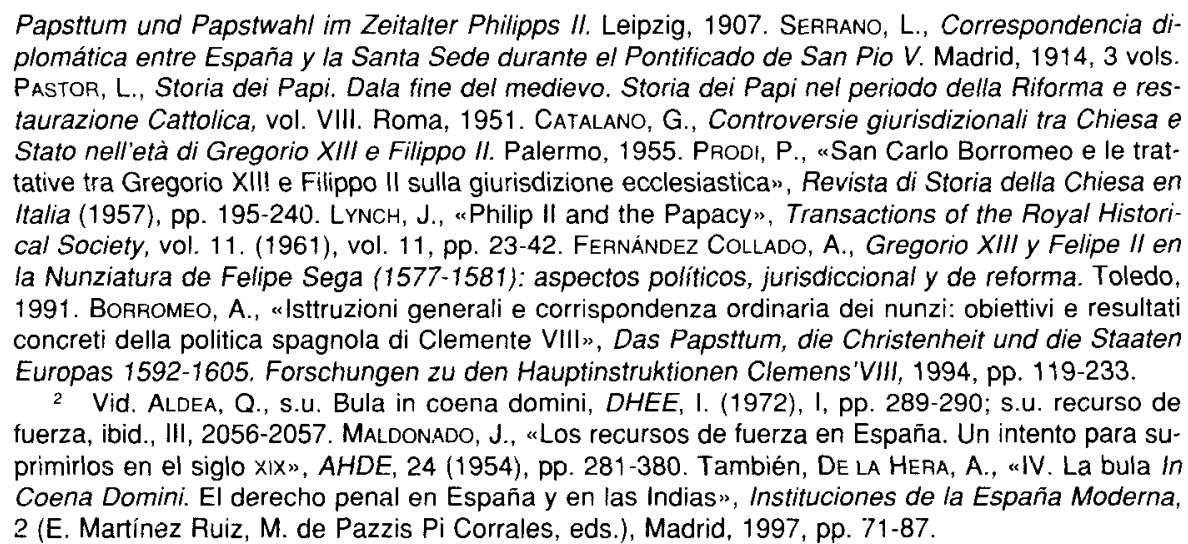

3 Vid. Mandonado, J., op. cit., p. 290

4 Los nuncios de esta forma lo señalaron en su correspondencia. Vid. MALDONADO, J., op. cit. DE LA FUENTE, V., La retención de Bulas en España ante la historia y el derecho. Madrid, 1865. Se considera el año 1525 como el de instauración del recurso de fuerza, no obstante. los tratadistas lo conceptuaron según el derecho de defensa inherente a la monarquía dontádolo por esta vía de una tradición inmemorial. En la documentación que hemos consultado no hemos encontrado ninguna precisión cronológica. Covarrubias, J., Máximas sobre recursos de fuerza y protección, con el método de introducirios en los tribunales. T. I., Madrid, 1829, p. 150. Vid. PASTOR, L., op. cit., p. 289. LAARHOVEN, J. VAN, «Cristianitas" et Réforme Grégorienne», Studi Gregoriani, vol. VI, pp. 1-96. Prodl, P., "Note sulla genesi del diritto nella Chiesa postridentina", Legge e Vangelo. Brescia (1972), pp. 191-223.

5 Vid. «discorso sopra la Monarchia di Spagna". Antecedentes e historia, impacto universal y responsabilidades, finales del siglo XVI, especialmente, el Cap. VI «Se tra christiani ci possa esser Monarchia universale altri che il Papa, e come si debba trattar con lui", Biblioteca Apostólica Vaticana (BAV), Barb. Lat. 5198, fol. 20v. Hay copia en Archivo Secreto Vaticano (ASV), Fondo Borghese, 1, 308. Vid. LuTz, H., "Kardinal Morone: reform, Konzil und Europäische Staatenwelt", ! Concilio di Trento e la Riforma Tridentina. Atti del Convegno Storico Internazionale, T. I, Roma, 1965, pp. 363-381. Bosbarch, F., "Humanisten und die Monarchia Universalis Politisches Denken und Politisches Handeln in der Zeit Karls V", Res Publica Litterarum. Studies in the Classical Tradition, IX (1986), pp. 37-47. LALINDE, J., “España y la monarquía universal», Quaderni Fiorentini, 
entre estados en la que los respectivos vínculos y relaciones se disponen en función de necesidades jurídicas. Lo que es común no sólo llama a una comunidad de fieles unidos bajo el pontífice ${ }^{6}$, sino a vínculos que son susceptibles de unir por razón jurídica y causa de necesidad ${ }^{7}$. A partir de aquí, tanto el recurso de fuerza como la bula In coena Domini se instituyen como principios legales de ambos supuestos, sancionados por la tradición y no sometidos a "opinión contraria». De esta forma tiene lugar la emergencia de principios "sustanciales", instituidos como «reglas seguras y ciertas" ${ }^{8}$, que adquieren la función de iura immutabilia, por razón jurídica, con la irrevocabilidad del recurso de fuerza ${ }^{9}$-como ocurre, por ejemplo, con el derecho de patronazgo real ${ }^{10}$, o la immunitas-, o del carácter permanente que Pio V le da a la bula in coena Domini ${ }^{11}$.

Como consecuencia del espíritu de reformatio surgido del Concilio de Trento, los esfuerzos de la Santa Sede se dirigen a obtener la ejecución de las disposiciones pontificias y con ellas, los supuestos conciliares, en su condición específica de autoridad espiritual. Pero frente a ello la monarquía presenta el recurso de fuerza como principio jurídico y legal inalterable. La consecuencia es que el conflicto se debatirá sobre los fundamentos constitutivos de la auctoritas y de la ejecución.

(1986), pp. 109-166. Fernández Albaladejo, P., «"Imperio de por si": la reformulación del poder universal en la temprana Edad Moderna» en, Fragmentos de monarquía. Madrid, 1992, pp. 168-184.

6 Vid. PARIS, J. OF, On royal and papal power (ed. J.A. Watt). Toronto, 1971, pp. 86-87. LE VAN BAUMER, F., "The conception of Christendom in Renaissance England", Journal of the History of ldeas, VI (1945), p. 14.

7 Cfr. PIRILLo, N., "Per la semantica dello Stato moderno. La metafora del tribunal: ragione, coscienza, civile", " vincolo del giuramento e il tribunale della coscienza (ed. N. Pirillo). Bologna, 1997, pp. 361-417.

8 De esta forma las calificará en la siguiente centuria el cardenal Sandoval en un informe que envía a Felipe IV en 1656. El texto lo utilizamos en nuestro trabajo "Uoluntas e lurisdictio: obediencia, ejecución y cumplimiento de la voluntad real en la Corona de Castilla el siglo XVIIn en, Monarquía, imperio y pueblos en la España Moderna (ed. P. Fernández Albaladejo) (Univ. de Alicante, mayo de 1996), Alicante, 1997, p. 670.

9 "Questo modo di procedere non si può totalmente levare, perche oltre la usanza di longo tempo, il tengano per iuridico, et non mancano scrittori dottissimi, che l'approvano per molte ragioni, e tutti l'usano tanto seculari, quanto ecclesiastici, et li capitoli, et capitolari istessi ogni volta che torna lor conto, ricorsono a questo soccorso...", "Istruzione del clero di Spagna", ASV, Misc. Arm. I-XV, Arm. II, 102, fol. 264r-269v.

10 Discurso político cristiano de un castellano viejo en defensa de su patria y de las regalías del rey vulneradas por los ministros de Roma, s.I. s.a., [siglo XVIII], B.N. VC/ 998/6. Vid. GuTIERREZ Martin, L., El privilegio de nombramiento de obispos en España. Roma, 1967. Hermann, CH., L'Eglise d'Espagne sous le patronage royal (1476-1834). Madrid, 1988.

11 "Queriendo que duren, y surtan sus debidos efectos estas Letras, y todo lo en elias contenido, hasta que por el Romano Pontifice que por tiempo será, se hagan, y publiquen otras semejantes", Lopez, J.L., Historia legal de la Bula in Coena Domini. Madrid, 1768, p. 44. Vid. CaTALANO, G., op. cit., pp. 32-33. 
En la Corona de Castilla, durante el reinado de Felipe II, la auctoritas como principio abstracto se apoya en un cúmulo de derechos juridicos adscritos a una "autorización antigua", y se encuentra imbuida de la idea de permanencia ${ }^{12}$. La función del recurso de fuerza, omitida por los pocos estudios que se han ocupado de él, de contravenir la autoridad sirve a este objetivo, pues frena cualquier alteración en derecho, y ello en unos momentos en los que el principio de reformatio, según los presupuestos tridentinos, se abría paso como auctoritas.

El recurso de fuerza se apoya, además y sobre todo, en la costumbre. Ello ejerce el papel de servir de enlace con lo "antiguo" en la búsqueda por dotar de inmutabilidad a la costumbre, y a la ley, como rasgos distintivos integrados en un concepto de reino propio ${ }^{13}$; todo ello como signo de perpetuidad del reino natural ${ }^{14}$. La permanencia e inmutabilidad de la costumbre y de la ley se constituyen sobre la idea de una "verdad" jurídica inmutable, en correspondencia con la ley sagrada ${ }^{15}$, pero se impone el significado jurídico frente al religioso. La condición de iura immutabilia no se recoge del derecho divino, como ocurre con aquellas leyes de origen divino adscritas al derecho canónico que poseen la propiedad de "inalterables", sino en conformidad con un precepto autorizado y sancionado por su uso y aceptación continuada. Aunque la inmutabilidad se recoge del pasado, se constituye como piedra fundamental del orden jurídico para el porvenir ${ }^{16}$. Por tanto, con la inmutabilidad no se trata de volver a un pasado mítico sino de conservar el reino natural para el futuro.

12 Vid. Borromeo, A., op. cit., p. 180

13 Vid. Mazzarino, S., La fine del mondo antico. Le cause della caduta dellimpero romano. Milano, 1995, pp. 164-170. Cfr. Koenisberger, H.G., "El arte de gobierno de Felipe Il», Revista de Occidente, 107 (1972), pp. 135-136. Garcia Marín, J.M. ${ }^{a}$, Monarquía católica en Italia. Burocracia imperial y privilegios constitucionales. Madrid, 1992. Galasso, G., Alla periferia dell'impero. II Regno di Napoli nel periodo spagnolo (secoli XVI-XVII). Torino, 1994.

14 Vid. Beneyto, J., Los origenes de la ciencia política en España. Madrid, 1949, pp. 270-271. García de Valdeabellano, L., Curso de historia de las instituciones españolas. Madrid, 1968, p. 413.

${ }_{15}$ Sobre la condición sacra, entendida como sinónimo de perpetuidad, del recurso de fuerza, el nuncio señala «... chi dicesse male di detto remedio considerato in se stesso sarebbe ripreso qui da laici et clerici, canonisti et theologi, come'uno che toccasse una cosa sacra, perche lo tengono per inventione santa et defesa dall'antichissimo e immemorabile costume et coriforme all'humor peccante et cervicosita per dir cosi della natione...", Carta del Patriarca de Alejandria de 6 de diciembre de 1597, ASV, Fondo Borgese, 81 a, fols. $567 \mathrm{r}-568 \mathrm{v}$ y $570 \mathrm{r}-573 \mathrm{v}$. La relación entre ley vieja y ley sagrada como signo de inmutabilidad la encontramos expresada en Antonio de Solís: "Toda la ley vieja y la ley de gracia, fueron fundadas sobre verdad, que es el mesmo Dios, como sobre piedra fundamental: y asi como el fundamento es firme y ha de durar para siempre: ansi el hedificio durara para siempre. La verdad del señor, que es su ley y sus milagros y evangelio durara para siempre", Consuelo de los estados. Meaina del Campo, 1576, p. 134.

16 Como recoge Eduardo Hinojosa y Naveros, Felipe II advirtió al Papa «...que no faltaría á su deber de dejar á sus hijos y sucesores en la justa posesión y señorío, y que, como soberano que era iridependiente en lo temporal, se haria a sí mismo justicia», op. cit., p. 203. 
Si la práctica de retención de bulas y letras apostólicas, con el recurso de fuerza, es reciente ${ }^{17}$, la costumbre como acto indeterminado por el derecho sirve para conceder fuerza de ley a un acto "repetido por cierto tiempo" como signo de una tradición inmemorial que debe regir para siempre ${ }^{18}$. Con el Concilio de Trento el conflicto entre reformatio y permanencia se hizo evidente cuando en 1553 Carlos V declaraba que correspondian al Consejo de Castilla por vía de fuerza los casos tocantes a la ejecución y cumplimiento de los decretos conciliares ${ }^{19}$. En este sentido, las consideraciones sobre la contravención de las disposiciones del Concilio, o las acusaciones al Consejo de Castilla debido a sus recelos por admitir sus edictos como en otros reinos ${ }^{20}$, relegan al Concilio no sólo al papel de servir de exaltación de la auctoritas dividida de una Iglesia particular, sino a integrar la idea de reformatio, de una Ecclesia semper reformanda ${ }^{21}$, pero necesitada de «remedios", en la sanción de un corpus legal «viejo», activado jurídicamente. De aquí surge la plenitudo quaedam iuris ${ }^{22}$ como un concepto jurídico y legal en el que se encuentra inserta la idea de inmutabilidad del derecho. La condición privativa del príncipe -expresión de un orden jurídico natural inmutable- dota a lo temporal natural de autoridad frente a la eventual ejecución de una reformatio espiritual

17 Nov. Rec. T.3 L.2 Ley 1, 1480. Si bien, en la correspondencia de la Nunciatura la legislación que se tiene presente es la de de Carlos V; la carta del Patriarca de Alejandría al cardenal AIdobrandino de 5 de noviembre de 1594, recoge que dicha práctica procede de los tiempos de Carlos V, ASV, Fondo Borghese, III, 23, fol. 499r.

18 De Soto, D., De la justicia y del derecho. Madrid, 1967, p. 76. Con respecto al recurso de fuerza, los ministros del rey se apoyaron en la costumbre inmemorial para defender su legalidad, a lo que los nuncios respondieron advirtiendo la novedad de la amplitud y condiciones con las que se presentaba en el siglo xv. No obstante, en Domingo de Soto nos encontramos con que, con respecto a la duración de tiempo que ha de exigirse para que la costumbre alcance fuerza de ley, “...no está determinado por el derecho. En unas cosas bastan, como dicen, dos actos, en otras tres, en otras diez», p. 77. Sobre la legislación al respecto, MALDONADO, J., op. cit.

19 Maldonado, J., op. cit., p. 298. El Consejo real se quejó de este control ante Clemente VIII. En carta a Felipe II de 22 de septiembre de 1593, afirma: "Noi veramente restiamo stupeti come si venga a tanto ardire che quel rispetto, che ha havuto, come doveva à questa Sta. Sede la Chiesa di Dio legitimamente congiunta congregata in Trento, et lo spiritu santo, el quale, si siamo Christiani, sappiamo certo, che vi assistitti, il quale volsi che in tutti i decreti, appertenenti à costumi, et a riforme, s'intendesse sempre eccettuata l'autorità del Papa, voglia il Conseglio di Spagna levare, et costituirsi in questo modo, et sopra il Papa, et sopra l'istesso Concilio, come se quel Conseglio havesse egli l'assistenza dello spirito santo, et l'infallibilità, et non il Papa, et il Concilio et è bella cosa, che dove in Spagna non piacciono i decreti del Concilio sopra la riforma, ardischino di dire che non gli hanno ricevuti...”, op. cit., fols. 17v-18r.

20 Vid. Prodi, P., «Note sulla genesi de diritto nella Chiesa post-tridentina", op. cit.

${ }^{21}$ Lemaitre, N., s.u. Riforma Cattolica, Dizionario Storico del Papato (ed. Ph. Levillain). Milano, 1996, II, pp. 1253- 1256.

22 Tomamos la expresión de Bernardo Giusti, al afirmar que «...la libertà ecclesiastica non è altro, che plenitudo quaedam iuris", Difesa della libertà ecclesiastica. Contro alcuni detrattori di Venetia. Roma, 1606, p. 7. 
que no competía sólo a la disciplina, puesto que el vínculo entre la monarquía y la Santa Sede era jurídico, sino a su consiguiente configuración legal: su ejecución y cumplimiento sólo será viable a partir de su institución e inserción legal en un orden jurídico natural «inalterable». Por tanto, una de las funciones más conflictivas del recurso de fuerza era preservar el orden natural, no de la reformatio espiritual, sino de cualquier alteración en derecho y, con ella, de los principios constitutivos de la auctoritas y de la ejecución.

El concepto de reino natural en el que se apoya en recurso de fuerza se constituye alrededor de la figura de un «rey defensor» de sus súbditos. De esta forma, el concepto de "jurisdicción universal» es relegado, pues la idea de defensa no afectaba a la iurisdictio, sino a una relación de lealtad. $\mathrm{Si}$ ello podía repercutir en el principio de exención del emperador ${ }^{23}$, son las repercusiones de esta exención en lo que suponía de alteración en la formación de los supuestos legitimadores del poder temporal, lo que repercutía en la constitución de lo "universal» ${ }^{24}$. La "separación jurisdiccional» que los nuncios y el papado reprobaron a Felipe II por causa del recurso de fuerza como algo propio de los "estados herejes» ${ }^{25}$, se presentaba no sólo como garante de la soberanía del príncipe temporal, sino por cuanto que impedía la dualización de las autoridades de Dios y del César, bajo el supuesto bíblico "Reddite quae sunt Caesaris Caesari, et quae sunt Dei Deo» ${ }^{26}$. La monarquía no se erigía en la encarnación del poder temporal según una dualidad de conceptos de represeritación, lo que llevaba necesariamente a excluir pretensiones de imperio ${ }^{27}$. La monarquia se define a partir de la idea de defensa y de permanencia del

23 Esta necesidad de exención la encontramos expresada en el reinado de Carlos $V$, Rodríguez Salgado, $M^{a}{ }^{a}$ J., «Patriotismo y política exterior en la España de Carlos $V$ y Felipe $l l$ », La proyección europea de la monarquía hispánica, Madrid, 1996, pp. 49-105. Mientras que en la doctrina, como es el caso de Diego DE CovaRRUBIAS, también se argumenta la independencia del emperador: “Príncipe... hay en el mundo que no están sometidos a ningún emperador o César por grande que sea y justísimamente son libres e inmunes de su jurisdicción... Luego la naturaleza y el derecho natural no conceden al Emperador la jurisdicción de todo el orbe", "De la justicia e injusticia de la Guerra y de la restitución de las cosas que los soldados toman en la guerra", en, Texto jurídico-políticos. Madrid, 1957, p. 45.

24 Sobre este concepto de jurisdicción universal vid. Covaralubias, D. DE, op. cit., pp. 45 y 51.

25 Pereña VICENTE, L., «Francisco de Vitoria y la unidad de Europa», Derecho de gentes y or ganización internacional, II. Santiago, 1957.

${ }_{26}$ Matt. 22.21. De ello se hace eco Fío V, «Risposta alla Istruttione data al Sor. Commedore. maggiore, ambtore del sermo. Rè Catholico", op. cit. Vid. TURAINI, M., "Tra diritto e teologia in età moderna: spunti di indagine", I Concilio di Trento e il moderno (eds. P. Prodi y W. Reinhard). Bologna, 1996, pp. 255- 269. LAARHOVEN, J. VAN, op. cit.

${ }_{27} Y$ ello no obstante que tal representación fuera finalmente recogida por la doctrina. Cfr. Herfie, P., op. cit., pp. 282-283. 
«reino natural» como principios necesarios en la consecución de la paz ${ }^{28}$. Supuestos en los que se apoyaba el recurso de fuerza: como «instrumento natural» ${ }^{29}$, se imbrica con la idea defensa y de protección como una obligación por «razón de oficio» que impide el sometimiento, permite la libertas y asegura la conservación del reino y la paz ${ }^{30}$. Al asegurar la inmutabilidad de la costumbre y del orden natural, se impide la pervivencia de las dos espadas en lo que de mutua dependencia legitimadora ello llevaba consigo ${ }^{31}$. El "reino natural» no se constituye como mímesis de lo universal sino frente a la dualidad ${ }^{32}$.

La monarquía de Felipe II, de naturaleza temporal, se mostraba como la materialización de derechos adquiridos, “...quia dominatur magnae parti mundi inter Chriftianos Principes habens quandam ex officio eminentiam» ${ }^{33}$. Se trataba de una preeminencia jurídica y legal, que no llevaba poderes excepcionales, que venía a confirmar el orden de otros reinos ${ }^{34}$. Al constituirse el vínculo jurídico entre el rey y el súbdito en lo temporal natural ${ }^{35}$,

28 “No parece se puede poner en duda ser la paz la que mas importa en el mundo siendo la discordia origen de quantos trabajos y miserias puede aver, y no de otra manera se goza lo que es vivir en el mundo sino es aviendo paz, y conformidad", Horozco y CovarRubias, J. DE, Paradojas cristianas contra las falsas opiniones del mundo. Segovia, 1592, p. 97v. Mientras que, frente a la idea común según la cual la unidad es el principio indispensable para la paz, advierte que es preferible la división a mantener una relación de discordia: "Y en quanto a la paz que el mismo Christo encargo tanto, no contradize la division que dezimos, porque es para tener paz con Dios", $p$. 98r. Vid. Pereña Vicente, L., op. cit., p. 107, y del mismo autor, "Introducción a la tesis española de la paz", Revista Española de Derecho Internacional, 16, 1-2 (1963), p. 15. También, KoENISBERGER, H.G., op. cit., pp. 140-141.

29 Así lo define Aldobrandino, cifre de 20 de diciembre de 1594: “...intorno a levar l'abuso della forza, quel che dicono i Ministri Regii in sua difesa, che è cosa antica et naturale di quei Regni, è di poca sostanza, et si può facilmente ribattere non essendo verisimile che $i$ vescovi, $i$ quali vengono nominati da S.Mtà. et dipendono da lui, vogliono abusar la loro autorità, oltra che questo rimedio della forza si usa più contra le provisioni Apliche., che contro altri, ef realmente è stato introdotto per questo, come se ne vede l'effetto...", op. cit., fols. $423 \mathrm{v}-424 \mathrm{r}$.

30 «Pero dicono alcuni, che non può mancar d'haver differentie tra Principi, quando per cio che li Rè tengono obbligation di difendere, e proteggere li vassalli, sicome li sommi Pontifici sono obligati a diffendere l'autorittà della Sede Apostolica", LóPEZ DE MONTOYA, P., Discorso sopra la giurisdittione et esentioni ecclesiastiche nel partre, della forza, [1593], ASV, SS. Spagna, 43, fol. 289r-295v. Hay copia en Fondo Borghese, III, 24, fols. 385r-388v, en donde figura el autor.

${ }^{31}$ Eventualidad que lejos de ser una rémora del pasado tuvo su expresión en la negativa de Pablo IV a reconocer la sucesión del imperio en Fernando I de Austria.

32 Prodi, P., cil concilio di Trento di fronte alla politica e al diritto moderno. Introduzione», Il concilio di Trento e il modenro, op. cit., p. 15.

33 BAÑes, D., op. cit., p. 94.

34 En Domingo Bañes encontramos dos definiciones de este concepto de dominio legal. Según la primera, “...dominum est facultas propia utendi re in omnes usus lege permissos"; mientras que para la segunda, dominio "...est idem quod potestas legitima et iuridica quae secundum leges et iura habetur», ibid. p. 73.

35 «Nam ex eo quòd Rex Catholicus supra omnia sua Regna, omnes qui habitant huismodi regiones sunt ei subiecti in temporalibus", BAÑES, D., p. 93. 
la monarquía se apoyaba en «razones legítimas» ${ }^{36}$, según un concepto de "dominio natural" formado como el fundamento constitutivo del reino, tomando como base los fortísimos vínculos de unión y de protección entre el rey y sus súbditos naturales; razones contractuales en las que se apoyaba el concepto de recurso de fuerza. Este dominio apelaba a derechos irrevocables constitutivos de la figura del «rey natural», y no a la potestas. De esta forma no existía el peligro de que la regia potestas se transformase en potentia ${ }^{37}$, y fuese susceptible de subordinar a la autoridad religiosa 0 temporal, pues, en cualquier caso, ni la potestas ni la potentia podían separarse de la justicia y del principio de defensa propio del «rey natural» ${ }^{38}$.

36 Ello lo encontramos expresado por Felipe II como sigue: "...potrete in generale dire a Sua Stà, che quello che noi et li re nostri antecessori habbiamo usato in nostri regni et stati respettivamente secondo la diversità delle Provincie, è stato tenendo antiqui privilegii apostolici et altre molte legitime ragioni et titoli, et che questo si è conformato per antiquissima et immemoriabile possessione...", lo cual ha sido no sólo tolerado por los pontífices pasados, sino confirmado por ellos, «Instruttione di quanto voi if Comendator maggiore di Castiglia del nostro Conssiglio di stato, et nostro Ambassator in Roma havete da fare in quella Corte", ASV, Misc. Arm. I-XV, Arm.Il, vol. 102, fols. $366 \mathrm{r}-373$ (bis).

37 La potentia era normalmente considerada de forma negativa. Juan DE HOROzCO Y COVA. RRUBIAS se hace eco de ello: «Entendida la potentia perniciosa por las plumas del aguila, que si con ellas se juntan las plumas de las otras aves se deshazen", Emblemas morales. Segovia, 1589 , p. $77 \mathrm{v}$. También de forma negativa la vemos expresada en Domingo DE SoTC, con respecto al imperio romano: «... para quienes el derecho estaba en las armas... y subyugaron muchas naciones en contra de la voluntad de ellas sin otro título más que el de que eran más potentes, y no se halla donde Dios les diera tal derecho', Relección de 'Dominio' (ed. J. Brufau Prats). Granada, 1964, p. 151. Con ello Domingo DE SOTo sigue fielmente la tradición cristiana y la doctrina de San Agustín sobre el concepto de "guerra justa", considerando como inicua a toda guerra de conquista, como las llevadas a cabo por el imperio romano. Vid. DANE, J.A., «Potestas/ potentia: Note on Boethius's De Consolatione Philosophiae", Vivarium, XVII (1979), pp. 81-89. BELLABARBA, M., «lus feudale Tridentinum. Dottrina giuridica e governo territoriale del principe vescovo Johannes Hinderbach (1465-1486)", I/ principe vescovo Johannes Hinderbach (1465-1486). Fra tardo Medioevo e Umanesimo. Trento, 12, p. 161. Cfr. MIAJA DE LA MUELA, A., “El derecho "totius orbis" en el pensamiento de Vitoria", Revista Española de Derecho Internacional, 18 (1965), pp. 358-360. Fernández Albaladejo, P., op. cit. Batiffol, P., et alii, L'Église et le droit de guerre. Paris, 1920. MERON, TH., Henry's wars and shakespeare's laws. Perspectives on the law of war in the Later Middle Ages. Oxford, 1993.

38 Juan DE HOROZCO Y COVARRUBIAS en su obra Paradojas cristianas contra las falsas opiniones del mundo. Segovia, 1592, se ocupa de argumentar este problema, así sostiene que "Quien considera to que vale en el mundo la grandeza y el estado de los Principes, y el ser señores de tan. tas tierras y de tantos vassallos co[n] que suelen conquistar el mundo, dificultoso se le hara de creer que este no sea poder, y que los tales no sean poderosos, siendo este el ordinario nombre que se les da aunque sea en la sagrada escritura quando se trata de ellos, y por la mesma razon sera dificultoso de entender q[ue] no ay en las cosas el que se llama poder o potencia, que solo entonces se dize no ser o ser embalde quando no se reduze a acto. Y según la proposicion de nuestra Paradoxa, avemos de reduzir el poder de las cosas y de las gentes a sólo la palabra de Dios...", pp. 154r-154v. A ello añade; «...ninguna cosa tiene poder de si mismo sino dependiente de Dios" (p. 155r), "En que se ve lo que podemos considerar del poder de Dios y su ley atando a los poderosos para q[ue] solo aquello que fuere co[n]forme a su volu[n]tad quiera, y no otra cosa, $y$ assi se viva en el mundo en paz y justicia. $Y$ donde no uviere esto se hechara de ver, que todo 
El príncipe recibe la potestas y sus facultades de rey del derecho -incluso la figura del emperador se adecúa en la tratadística a este concepto de potestas legal ${ }^{39}$. Este derecho personificado en el recurso de fuerza como principio jurídico inalterable asegura la pervivencia de la legalidad antigua a favor de la deseada conservación y seguridad de los estados, por contraposición a la idea de ruina y pérdida de los reinos sujeta a alteraciones en derecho ${ }^{40}$. En el "vínculo natural" entre rey y súbdito, de un derecho natural inmutable, se encuentra la clave de su conservación ${ }^{41}$; sólo de su comunión jurídica surge la potestas. Al no poder separarse ésta de la iurisdictio ${ }^{42}$, la suspensión de la ejecución, y con ella la separación jurisdiccional, con el recurso de fuerza se presentaba como una necesidad jurídica: separar la obediencia del súbdito, mediante la exención, de la iurisdictio espiritual. A partir de aquí, la conservación del reino y la comunión entre rey y súbdito, no obstante los esfuerzos de la Santa Sede -en su intento de dualizar las relaciones entre el poder espiritual y el poder temporal-, por situarla en la relación entre un "rey católico" y la observancia de la autoridad eclesiástica ${ }^{43}$, se sitúa en un rey defensor de sus

es tyrania y desconcierto sin haver ley ni justicia. $Y$ pues esta es la que declara el verdadero poder y se limita conforme a la palabra de Dios...", p. 158r. SoTO, D. DE, Relección..., pp. 77-79. MIAJA DE LA MUELA, A., op. cit., p. 354. La unión entre justicia y potentia se hace evidente en el caso surgido con motivo de la sucesión de Felipe Il al reino de Portugal, vid. HinOJOSA Y NAveros, E., op. cit., pp. 280 ss.

39 Covarrubias, D. DE, op. cit.

40 Sobre las diferentes causas que lleva a la pérdida de los reinos, el cardenal Aldobrandino y los ministros hispanos se intercambian mutuas acusaciones sobre esta eventualidad. Para la Santa Sede, la causa se encontraba en la pérdida de la autoridad y leyes eclesiásticas; mientras que, como el propio Aldobrandino refiere en una carta de 2 de abril de 1595 a los nuncios Mellino y Catetano, los ministros hispanos acusan, a su vez, a la Santa Sede de la pérdida de los reinos que se han separado de ella, ASV, Fondo Borghese, II, 472, fol. 171r. Sobre la idea de pérdida y decadencia de los reinos vid. Mazzarino, S., op. cit. A este respecto Felipe ll aconseja a su hijo Felipe III, «...os haréis conocer más como celoso conservador de vuestros derechos que como usurpador de los ajenos", Conde de Atares, "Consejos de Felipe II a Felipe IIl», Boletín de la Real Academia de la Historia, CXLI (1957), p. 662.

41 Extremo que lo vemos reflejado en la intención de obtener un soberano natural para los Paises Bajos, Rodriguez Salgado, M. ${ }^{a} \mathrm{~J}$., Un imperio en transición. Carlos V. Felipe II y su mundo. Barcelona, 1992, p. 125.

42 “...toda potestad consiste en la jurisdicción, ni es otra cosa que la jurisdicción", VẢZQUEZ DE MENCHACA, F., Controversias fundamentales y otras de más frecuente uso, vol. Ill (ed. F. Rodriguez Alcalde). Valladolid, 1933, p. 163.

${ }_{43}$ En una carta que Busto de Villegas, gobernador del arzobispado de Toledo, escribe a Felipe II se refleja esta idea según la cual las desgracias del imperio romano se explican por el hecho de que se "atrevieran" con las cosas de los templos, "Carta que escribió al rey don Felipe 2. Busto de Villegas, gobernador del arzobispado de Toledo en respuesta de la que su Majd. le escribió sobre el Breve que su Santidad le concedió para la enajenación y venta de los vasallos, y jurisdiccion de las Iglesias, y monasterios", Toiedo, 25 de julio de 1574, BAV, M ss. Chigiani. O.II.24, tols. 230v-231r. Con motivo de un expolio de Palencia, el nuncio confirma esta idea: “..è pura giustitia et anco stabilimento et perpetuatione de suoi Regni; sapendo bene $\mathrm{S}$. Mta. con tante- 
súbditos naturales, con arreglo a una idea de "república temporal» ${ }^{44}$. Puesto que, por razón inductiva, contra la autoridad del pontífice no existía ni exención ni prescripción ${ }^{45}$, en la vertiente natural de lo temporal -a lo que era ajeno tanto el poder espiritual como el temporal del pontífice-, se evitaba la constitución de una jurisdicción universal in spiritualibus sobre la base de representación de legitimación de la dualidad de potestades ${ }^{46}$. De esta forma, y por la parte eclesiástica, se evitaba que dicha potestas se tranformase en una potentia espiritual susceptibles de constituir dominio ${ }^{47}$.

esperienze che la caduta de altri Regnii hanno havuto principio et potissima causa dal cominciare à poco à poco à voltar le spalle alla Sta. Apca. Sede", "Informatione delle danni che riceve la Collettoria di Spagna, et suoi riimedii. Mandata da Mosnr. Orsino con sue lettere delli 20 settembre 1594", ASV, Fondo Borghese, III, 83 c, fol. 78 r. A ello, podemos añdir: «...questa introduttione dell" "auxilio della forza è di gran scandalo, et di pessima conseguenza; impero che quando si lascia la briglia a i magistrati secolari di impugnar l'autoritrà et giurisdittione ecca., di qui nasce il dispresso de superiori ecci., et della Chiesa, et pian piano i Popoli vanno sdrucciolando nell'heresia, et finalmente si partono non solo dall'obedienza della Chiesa Sta., ma anco da quella delle leggi civili, et dal Principe temporale, donde seguono poi quelle confusioni, et sovversione de Regni, et stati, le queli si sono vedute, et si veggono tutt. ${ }^{2}$ pur troppo frequenti nel tempo nostro, et nella $\mathrm{Ch}$ ristianità tutta", Instruttione sopra le cose di Francia a Monsig. Camillo Caetano, Patriarca di Alessandria, Nuntio in Spagna», Roma, 27 de octubre de 1592, ASV, SS. Spagna, 325, fols. 7v-8r. Estas instrucciones están publicadas por BORROMEO, A., op. cit., pp. 206-215.

${ }_{44}$ Ctr. StRAdLing, R.A., Europa y el declive de la estructura imperial española, 1580-1720. Madrid, 1981 , p. 46.

45 «...nelle cose ecclesiastique l'autorità del Papa, contra la quale non si può allegare esentione, nè prescrittione alcuna, perche come non si possono allegare queste cose contra Dio, così ne anco contra it suo Vicario...", Bernardo Giusti, op. cit., p. 11.

46 De aqui la insistencia de Felipe II y de sus ministros en promover la condición temporal del clero como súbditos. Extremo que no dejó de suscitar protestas de la Santa Sede: “...chi non considera nel Papa, et ne le cose ecclesiastiche, altro che temporalità, non può si non iudicar male, et dar consigli pernitioso, che al fine torna in breve tempo contra l'istesso Principe, et il suo Regno...", "La scrittura de che si fà mentione ne la precedente lettera [al cardenal Alessandrino] et che si mandò c. essa è la seguente", 2 de marzo de 1568, ASV, Misc. Arm. I-XV, Arm. I, vol. 108 , fols. $111 \mathrm{v}-115 \mathrm{r}$.

47 En una consulta sobre si el monarca podía con buena conciencia pedir al pontífice licencia para vender los vasallos de los obispos e Iglesias, para resistir la armada del turco y asegurar la mar y puestos de sus reinos, firmada por el obispo de Canarias, Melchor Cano, Bartolomé de Miranda provincial de la provincia de España de la Orden de Predicadores, el doctor Gallo, catedrático de Biblia en Salamanca, y Alonso de Castro. predicador del convento de San Francisco de dicha ciudad, estando reunidos en presencia de su alteza, el príncipe Felipe, el 26 de agosto de 1553 , sostienen con respecto a dicha potentia que con la venta "...se quita la autoridad a los prelados la cual es necesaria en la Iglesia para el castigo de los súbditos y para resistir a los poderosos vecinos y comarcanos que sueien hacer injuria a las Iglesias, y aunque en este tiempo por la justicia y potentia de los reyes que tenemos no hay qué temer en esto podrían adelante otros tiempos es también necesaria la autoridad y potentia de la Iglesia para resistir a los herejes se podrian levantar como se ha visto por experiencia en Alemania donde con el favor y sombra de su Majd. por la potentia temporal que tienen allá los prelados se han conservado en religión sus súbditos y vasallos y faltando esta no hubiera quedado esa poca de religión que hay en aquellas partes», ASV, AA. Armadio l-XVIII, n. ${ }^{\circ} 4.205$, fol. $2 v-3 r$. 
La función defensora propia del príncipe lleva a que la condición jurídica y legal de la potestas, constituida en función de regulis iuris y «razones legítimas" como principios "sustanciales" e iura immutabilia, se integre en la constitución del "reino natural», poniéndose al servicio de aquel oficio de protección, no del «señorío». Con la separación jurisdiccional, el "reino natural" conservaba su permanencia y representación en lo "general» ${ }^{48}$, lo que afectaba a la constitución de la universalidad espiritual del pontífice, pues ello traía consigo la constitución del concepto temporal de defensa sobre el que se apoyaba la idea de paz; en detrimento del vínculo de armonía y de concordia entre el poder temporal y el poder espiritual característico de una unitas espiritual en lo universal, como fue defendido por los pontífices ${ }^{49}$. En función de este concepto de paz se constituye la idea de defensa de la religión católica en Felipe II. La defensa de la religión es una consecuencia de la paz, no al contrario ${ }^{50}$.

En este sentido, la herejía y la Reforma, expresada con la desobediencia al papa, no planteaba sólo un problema dogmático y meramente religioso. Con la herejía se plantea un problema de autoridad ${ }^{51}, 0$, para ser más precisos, jurídico ${ }^{52}$. Felipe II fue objeto de la acusación de herejía por parte de los papas con motivo del recurso de fuerza, al que se conceptúa como "herejía jurídica» ${ }^{53}$. La ruptura jurisdiccional —que no la

48 Esta expresión fue utilizada con frecuencia en el Concilio de Trento frente al concepto de universal, utilizado en Constanza y Basilea; no obstante los Papas siguen valiéndose de este último concepto en el siglo xvi, vid. Minnerath, R., Histoire des conciles. Paris, 1996, p. 80.

49 Dicha idea se expresa como sigue: "La tercera dificultad hacen los tiempos que certisimamente son peligrosos especialmente en lo que toca a esta tecla de Santo Pontifice, y su autoridad la cual ninguno por maravilla ha tocado que no desacuerde la armonia, y concordia de la lglesia...", [memorial anónimo], 1555, BAV. Barb. Lat. 3509, fols. 9r-28v.

50 "Guerras justas son las que se emprenden, no por ambición o apetito de conquista de nuevos Estados, sino, principalmente, por conservar la pacificación de los propios, por la religión católica, por la libertad, por la defensa propia, parientes, enfermos y oprimidos, por recuperar lo usurpado", CONDE DE ATARES, III, op. cit, p. 668.

51 BRUN, J. LE, "Autoritè doctrinale, définition et censure dans le catholicisme moderne. Notes critiques", Revue de l'Histoire des Religions, XXXI-3 (1994), p. 341.

52 Como se ve reflejado en un escrito que se entregó a Felipe II el 2 de marzo de 1568, ASV, Misc. Arm. I-XV, Arm. I, vol. 108, fols. 111v-115r. Vid. BOCKENFöRDE, E.W., “La formazione dello stato come processo di secolarizzazione», Cristianesimo e potere, Atti del seminario tenuto a Trento il 21-22 giugno 1985 (eds. P. Prodi, L. Satori). Bologna, 1986, p. 109. Prosperl, A., Tribunale della coscienza. Inquisitori, confessori, missionari. Torino, 1996. JEDIN, H., Geschichte des Konzils von Trient. I. Der Kampf um das Konzil. Freiburg, 1951 (utilizamos la versión italiana, Brescia, 1949).

53 Como herejía considera el cardenal Aldobrandino la injerencia jurisdiccional al cuestionarse, con esta actitud de los ministros del rey, la superioridad del poder espiritual sobre el temporal, "Lettere di Aldobrandino a los Nuncios Mellino y Camillo Caetano", 2 de abril de 1595, ASV, Fondo Borghese, op. cit. fol. 171r. Asimismo, de heréticos califica Clemente VIII a los ministros de Felipe II, al persistir "ostinadamente" en sus intromisiones jurisdiccionales, Carta del cardenal Aldobrandino al Nuncio, 20 de abril de 1597, ASV, SS. Spagna, 324, fol. 47r-50v. 
permanencia de un orden universal de este cuerpo místico, extremo que la reforma no alteró ${ }^{54}$, suponía la exención del "reino natural» y de lo temporal del poder espiritual. Además, merced al recurso de fuerza Felipe II podía incumplir las disposiciones pontificias ${ }^{55}$, evitando formalmente el cisma, pero adoptando una postura semejante a la practicada por los «estados herejes", como fue denunciado por los pontífices ${ }^{56}$.

Se introducía la obediencia del monarca a Roma en una relación de lealtad, dando prioridad a los medios no judiciales, y cuya determinación se lleva a cabo con una negociación. El resultado de la separación jurisdiccional con el recurso de fuerza, es que el nuncio como juez competente en lo jurisdiccional, cuyo tribunal creara Carlos $V$ en 1537, inicialmente, queda desplazado ${ }^{57}$. A partir de este momento, las relaciones entre el príncipe temporal y la Santa Sede y los conflictos entre ambos no podrán medirse en términos de jurisdicción. Ello se plasmará en la preferencia dada, en las negociaciones con el papado, a la embajada en perjuicio de la Nunciatura. La lealtad a Roma quedaba sujeta a las reglas de la "razón de Estado" ${ }^{8}$. La iurisdictio se circunscribía a las relaciones entre el clero y el rey o entre

54 Baumer, F.L., "England the Turk, and the Common Corps of Christendom», The American Historical Review, L, n. ${ }^{\circ} 1$ (1944), pp. 26-48. Phod, P., “Controriforma e/o Riforma Cattolica: superamento di vecchi dilemmi nei nuovi panorami storiografici», Römische Historische Mitteilungen (1989), pp. 227-237.

55 Vid. la carta de Zúñiga al rey de 14 de octubre de 1569, Serrano, L., op. cit., pp. 163-164.

56 P. López de MONTOYa que escribe un discurso sobre la retención de bulas con el recurso de fuerza recoge esta lectura: "L'impedir et detener li mandati Apostolici tollende violentiae non è discoperta imbriacatura di disobedza. pero pare, che stia visino a essa", op. cit. El nuncio, con respecto a las relaciones entre la monarquía y la Santa Sede, advierte que en los países herejes, "...essendo altrata la osservanza de sacri canoni godendo della libertà et scuotendosi dalle loro spalle il suave giogo del Pastor Universale hanno perso la guida et regola infallibile del buon'governo et per permissione divina hanno smarrito il camino diritto della Sta. Sede hanno ricalcitrato al Concilio di Trento et sono state dominate dall'eresia la quale con nessun'altra occasione prende tanto vigore quanto dalla diminutione et oppresione della sede Apostolica contra la quale nel secolo presente s'indirizza il scopo principale degl'heretici, li quali di nessuna cosa godono tanto come di vedere che li Ministri del papa el del Re in Spagna sempre sono alle mani et che se bene nel nome et nell'apparenza sł professa osservanza et riverenza all'ordini di S.Sta. non di meno nella sostanza delle cose et nell'intrinseco s'imppedisce l'essecutione degl'ordini di Roma et viene limitata quelia potestà la quale mostrano d'haver in veneratione et si tiene cosi poco conto delle scommuniche Papali ch'è venuto per Proverbio che non è buon'Alcalde ò Corregidore chi non sta scommunicato otto mesi dell'anno", [Memorial del Nuncio, Patriarca de Alejandría, para Roma, Cardenale Aldcbrandino], enviado con carta de 6 de diciembre de 1597, op. cit.

57 Y ello no obstante los esfuerzos de los nuncios por constituirse en tribunal judicial de apelación: «Dunque per diminuire almeno tali inconvenienti e bene che il Nuntio si faccia intindire, che egli è sempre pronto a rimediare a ciascuno che si sinta aggravato da decreti di qualunque giudici...", "Instruttione d'alcune cose di Spagna in materia di giurisdizione per il Nuntio di Spagna" (1591), ASV, Misc. Arm. I-XV, Arm. I, vol. 89.

58 Así lo dejó expresado Felipe II en las instrucciones dirigidas a Felipe III, CONDE DE ATARES, op. cit., p. 661 . 
el clero y el pontífice. En este caso, la consecuencia de la exención es que frente a la unitas jurisdiccional impulsada por el papado se impone la comunicación jurisdiccional entre sujetos jurídicos, que implica el ejercicio de la voluntas, frente a cualquier orden externa no sometida a derecho. Queda asegurada la eventual desobediencia.

El problema que, consecuentemente, tiene planteado la Santa Sede y alrededor del cual se debate el conflicto surgido con respecto al recurso de fuerza durante el reinado de Felipe II es el de integrar la autoridad espiritual en unos referentes conceptuales y razones inductivas en derecho que permitan su aplicación legal como auctoritas pública. Sobre todo, de lo que se trata es de obtener la ejecución de la autoridad espiritual, por razón de religión, sin la aprobación previa, y con ello determinar la constitución legal de la obediencia al pontífice.

Como consecuencia del Concilio de Trento, dichos referentes conceptuales y dicha obediencia se constituyen en la fuente de legitimación de una auctoritas eclesiástica que acude a razones espirituales a las que se quiere impregnar de un valor jurídico y universal específico, con el objeto de obtener su ejecución e irrevocabilidad. La consideración de la obediencia a la jerarquía eclesiástica como síntoma de santidad, responde a esta exigencia ${ }^{59}$. La declaración por el Concilio de Trento del derecho divino de la immunitas - aunque también del humano- se integra en la misma aspiración ${ }^{60}$. El valor espiritual que posee la bula In coena Domini es evidente, con el enaltecimiento de la transubstanciación ${ }^{61}$, de indudable significado tridentino ${ }^{62}$, en la constatación de una potestas espiritual preeminente. Sin embargo, Pio $V$ recuerda a Felipe II que, en materia de gabelas, además de circunscribirse la bula a los términos de la razón, y a las disposiciones de los sagrados cánones, se apoya «...da chi ne hà la podestà" ${ }^{63}$. La materialización de esta "podestà" se adscribe al campo de la contravención, mediante censuras y excomuniones, no al "señorío" y a la lex espiritual sagrada. Los vínculos de la bula con los derechos tradicio-

59 SODANO, G., "ll nuevo modello di santità nell'epoca post- Tridentina», I tempi del Concilio, Religione, cultura e società nell Europa Tridentina (eds. C. Mozzarelli e D. Zardin). Bulzoni Roma, 1997, pp. 189-205.

60 Downs, J.E., The concept of clerical immunity. Washington, 1941, pp. 29-30.

61 Vid. Benedictus ARETIUS, Sermones tres de coena domini. Lausannae, 1578.

62 Filguera, M.A. DE, Suma de casos de conciencia que se disputan en la teologia moral. Tomo primero: en que se trata todo lo perteneciente a los sacramentos, también de las indulgencias, y Bula de Cruzada. Madrid, 1684, pp. 67-70. VISMARA, P., "ll cattolicesimo dalla "riforma cattolica" all'assolutismo illuminato", Storia del cristianesimo. L'Età Moderna. Roma, 1997, pp. 151-290.

63 "Risposta alla Istruttione data al Sor. Commedore. maggiore, ambtore. del sermo. Rè Catholico", op. cit. 
nales de la Iglesia, avalados por su publicación por los papas medievales, son los que le proporcionan su viabilidad con la legitimidad de una razón jurídica y la autorización de un derecho que obliga a todos los estados a la legitimación de los principios constitutivos de su propia sustentación legal, es decir, a partir de lo común legal: la plenitudo quaedam iuris. Así, el hecho de que en la Bula de Cruzada se mencionase como obligatoria la Bula de la Cena confirma la sanción regia de una legitimidad que también obliga al monarca ${ }^{64}$. Por lo que la bula lejos de conculcar la costumbre inmemorial, argumentada por Cesare Speciano ${ }^{65}$, la sanciona. En este sentido las novedades introducidas por Pio V, como lo era el hecho de su publicación fuera de Roma, lo que afectaba a los reinos italianos del monarca ${ }^{66}$, se justifican, bien en función del derecho y de la costumbre practicada por los papas de introducir novedades acordes con el tiempo ${ }^{67}$-en lo que supone "...un continuare il stile antico et consueto della chiesa" 68 -, bien por el valor "general» que poseía la publicación de la bula por los papas medievales ${ }^{69}$. Estos derechos no confirman el derecho divino de una potestas espiritual renovada y potenciada con el ejercicio del poder y de la idea de reformatio ${ }^{70}$, sino que se constituyen por sí en derechos sancionados por la tradición y, por tanto, en la consagración de la cos-

64 Pastor, L., op. cit., p. 298.

65 PRod, P., "San Carlo Borromeo...", op. cit., p. 197. Del mismo modo se expresa un memorial enviado por Monsr. Orsini con su correspondencia de 20 de septiembre de 1594 a la Secretaría de Estado: “...sempre ricorrono al med.’ refugio, dicendo che questa è preemineza Regia, et così si usa qua: ancora che segli repliche che la Bolla in Coena Domini toglie a fatto ogni privilegio, costume, usanza, et consuetudine ancorche immemoriabile quando ci fusse", Informatione delle danni che riceve la Collettoria di Spagna, et suoi rimedi, ASV, Fondo Borghese, III, 83 c. fol. $77 \mathrm{v}$.

66 Vid. PONTIERI, E., “ll papato e la sua funzione morale e politica in Italia durante la prepondenza spagnola», Archivio Storico Italiano, XCVI (1938).

67 Así, según Pio $V$, es legítimo añadir a la Bula “...alcune parole nuove et inusitate nelle altre antiche, Nel che però chi ben considera, troverà che è uso consueto aggiungere et scenare a detta Bolla varie cose, secondo le qualità degli abusi per la varietà de tempi hanno ricercato, come appare nella Bolla di Papa Martino Quinto, et di Clamente Settimo, et di Pauolo Terzo, ove erano più cose che nelle sussequenti, Alle quali di poi pergli altri che seguirno, s'aggiunsero altre cose et cosi di mano in mano sempre s'è fatto secondo l'occorrenze necessarie per la salute de fedeli, si come ancor li Principi secolari et particolarmenre sua Mtà. nelli suoi stati fà nuove leggi secondo giudica esser necessario", "Risposta alla istruttione data...".

68 Cata del cardenal Alejandrino a Castagna, 17 de agosto de 1568, SerRANO, L., op. cit., T. II.

69 De este modo se expresa Pío $V$, y ello por cuanto que «...procurando sua Stà continuamente in ogni maniera che può, sequendo il pastoral offitio suo, di emendare gli abusi, et introdurre nei popoli quella cristiana disciplina et religione che si conviene, si come in Roma et in altre città non cessa di fare particolari processioni, seguendo le occorrenze et bisogni loro, cosi ove gli abusi sono più sparsi et universali non può mancare di fare ancora ordini generali che provedano sufficientemente ad ogni luogo...», "Risposta alla Istruttione data al Sor. Commedore. maggiore, ambtore del sermo. Rè Catholico", op. cit., fol. $374 \mathrm{v}$.

70 Downs, J.E., op. cit. 
tumbre como fuerza legal ${ }^{71}$. Lo común legal sancionaba el recurso de fuerza. La bula In coena Domini, aunque activase la potestas espiritual del pontífice, tuvo que circunscribirse a servir de activación de una razón jurídica, como un "acto solemne" e «instrumento público» ${ }^{72}$; cuya ulterior ejecución en materia de inmunidad se efectuará por medio del privilegium inmunitatis con los indultos papales. Con este instrumento, la plenitudo potestatis papal, mediante la ayuda al rey como un acto de servicio, se vincula con la libertad jurisdiccional del estado eclesiástico ${ }^{73}$. Como el recurso de fuerza ${ }^{74}$, la función de la bula era suspender la ejecución, no instituir o ejercer la propia autoridad. Su publicación como un acto de jurisdicción no podía constituirse en un acto espiritual de la plenitudo potestatis papal sino, al contrario, como un "acto solemne" de sanción del privilegio ${ }^{75}$; siendo esta sanción la que permite la permanencia de los vín-

71 Cfr. Bendiscioli, M., "La bolla «In Coena Domini» e la sua publicazione a Milano nel 1568», Archivio Storico Lombardo, 541 (1927), p. 388.

${ }_{72}$ Ello en consonancia con otras disposiciones pontificias como la excomunión mayor y caducidad de dominio, y absolución del vínculo de fidelidad de los vasallos "a los hijos de iniquidad" del reino de Nápoles, acto solemne que se debía registrar sacando de él los notarios distintos tras. lados, "a fin de hacer válida y perpetua su memoria», CÁNOVAS DEL CASTILLO, A., "Roma y España a mediados del siglo XVI», Revista de España, T. II, parte II (1868), p. 447.

73 El Nuncio, Patriarca de Alejandría, así los afirma, refiriéndose al recurso de fuerza en el memorial enviado al cardenal Aldobrandino el 6 de diciembre de 1597: “ll 2. ${ }^{\circ}$ punto è ch'al servitio di V.Mtà. conviene assentare et concertare queste materie con la Sta. Sede Apostolica per li tempi presenti et futuri perche l'unione della sua Corona con li Sommi Pontifici è necessaria per la conservatione et stabilmento commune et nessuna cosa è più atta à rompere questo ligame come la contesa della Giurisdittione perche li ministri per mano dei quali forzosamente queste materie gelose passano sogliono per il zelo che tengono della grandezza et gratia delli Principi fomentare le discordie et alterare gl'animi di chi governa sotto il falso pretesto di stato et l'heresia che non puo intrare in questi Regni con la disseminatione di false dottrine de Regni vicini per l'esquisita diligenza che $V$. Mtà. usa può tacitamente entrare con la vanità di questa superiorità di giurisdittione per il disprezzo notorio di quelli che administrano la Republica delli Motu propii de sommi Pontifici et censure in essi contenute et in voler restringere censurare et interpretare la plenitude della potestà Pontificia", op. cit., ASV, Fondo Borghese, III, 81a, fols. 574r-584r. Vid. WATT, J.A., "The use of the term "Plenitudo Potestatis" by Hostiensis", Proceeding of the Second International Congress of Medieval Canon Law, Boston College (12-16 august 1963), Monumenta luris Canonici, serie C: subsidia, vol. I. Città del Vaticano, 1965, pp. 161-187.

74 Alonso. S., El pensamiento regalista de Francisco Salgado de Somoza (1595-1665). Contribución a la historia del regalismo español. Salamanca, 1973, pp. 116-123.

75 Monsr. Sega se hace eco de esta cuestión al sostener: «Aunque las dificultades que se oponen al libre ejercicio de la jurisdicción eclesiástica parece nacer de los Ministros, deriva realmente de su Majd. y desaparecen cuando á los intereses de la Corona conviene. Asi, por ejemplo, la Bula de la Cruzada se publicará en las calles con tambores y trompetas... porque se publica cosa que, si bien constituye un acto de jurisdicción de su Beatitud, reporta á su Majestad provecho manifiesto. Mas si se habla de publicar la Bula In coena Domini, que es también acto de jurisdicción de su Santidad, pero no de la índole del precedente por lo que afecta á los Ministros de su Majd. en muchos capitulos, es preciso promulgarla, en cierto modo, clandesinamente... Y lo que acontece en el caso de la publicación de estas dos Bulas, apliquelo V.M. á todos los que pueda ofrecerse en el ejercicio de la jurisdicción eclesiástica en estos Reinos...", HiNoJOSA Y NAVEROS, E., op. cit., pp. 244-245. 
culos en el ejercicio de un acto de voluntad con el consentimiento o, en su caso, con la contravención, como medios no judiciales. Con lo que la ejecución de lo espiritual no podía constituirse por razón de religión al margen de la aprobación.

En conformidad con la convergencia legal de la plenitudo quaedam iuris, la concepción de la herejía como menoscabo de la libertad y auctoritas de la Iglesia ${ }^{76}$, nos muestra que las fuentes de legitimación de la autoridad espiritual se insertaban en el campo del privilegio, en correspondencia con el poder temporal, y no meramente en su condición espiritual ${ }^{77}$. En función de este privilegium Felipe II legitimaba su autoritas con las concesiones dadas por los pontífices a lo largo del tiempo ${ }^{78}$. Y como expresión del privilegio, la libertad de la Iglesia exaltada por el papado, se afirmará, no sólo en la potestas espiritual, sino en la iurisdictio adscrita al clero castellano en su calidad de servidor del rey ${ }^{79}$, y en los privilegios del estado eclesiástico sancionados por los monarcas y príncipes temporales ${ }^{80}$. El papel de custodia de esta libertad, en tanto que reconocimiento de derechos privativos, desempeñado por la Santa Sede como refrendo de la autoridad papal ${ }^{81}$, confirma que la auctoritas de la Iglesia no se canaliza en función de su condición preeminente específica, por “reverencia» a la religión, en cuanto que potestas espiritual y en su vocación universal - no obstante que la publicación de la bula In coena Domini por Pío $V$ se adscribiese a su valor

76 GuIraud, J., Histoire de I'Inquisition au moyen age. L'Inquisition au XIlle siècle en France, en Espagne et en Italie. T. II, Paris, 1938, pp. 435-436

77 De este modo lo defendieron los papas. En una instrucción al Nuncio, obispo de Lodi, con motivo de su nombramiento en 1581, está presente la protesta del Papado contra los abusos que se cometian en España, en detrimento de la jurisdicción y disciplina de la lglesia, y en menoscabo de la autoridad del Papa y de los derechos y privilegios de la Curia Romana, HinoJosa y NAVEROS, E., op. cit., p. 250.

78 Como ha destacado A. BORRomeo, al afirmar que cuando Felipe II intenta establecer una restricción de la libertad e inmunidad eclesiástica lo hace, "...richiamandosi a presunte concessioni, tacite o espresse, della Santa Sede», op. cit., p. 180.

79 Así se refleja en la carta que Clemente VIII escribe a Felipe II el 22 de septiembre de 1593 en la que, con motivo del recurso de fuerza, el pontífice identifica la ruina de la jurisdicción con la ruina de la religión: «...vuol dire la depresione et estintione della religione, ma anco della giurisdittione temporale, come i Regni vicini s'insengano...", ASV, Fondo Borghese, II, 471, fol. 17r-18r.

80 Bernardo Giusti afirma que la libertad eclesiástica, habiendo sido ordenado por Dios, ha sido acrecentada por los privilegios dados por los príncipes, op. cit, p. 7 . No obstante la Nunciatura se queja de esta pretensión, defendiendo el origen divino de las exenciones eclesiásticas: "Che l'essentione de clerici quanto alla temporalità non sia de iure divino che li privilegii et preeminenze ch'il Papa et vescovi tengono in queste materie di essentione siando conceduti da Principi secolari et possano esser limitate et ampliate conforme alli tempi et utilità publica", Memorial del Nuncio, Patriarca de Alejandría, para Roma, Cardenale Aldobrandino enviado con carta de 6 de diciembre de 1597, op. cit.

81 Vid. "Scrittura data a Papa Gregorio XIV sopra li abusi di Spagna", ASV, Misc. AA. Arm. IXVIII, n. ${ }^{\circ} 4.205$, fol. $32 r-33 r$. 
general ${ }^{82}$-, sino en su compenetración jurídica con el privilegio a cuyo servicio se colocaba una potestas iurisdictionis que era compartida con el estado secular y el estado real en la Corona de Castilla ${ }^{83}$. Elio llegó al extremo de que la Nunciatura se encontrase en la necesidad de adscribir la autoridad eclesiástica a la potestas iurisdictionis como ratio inductiva, en consonancia con el derecho castellano ${ }^{84}$. Dicha ratio es la que une en la sanción del privilegio y de la libertad; sanción que necesariamente tenía que anteceder a la ejecución, pues en caso contario se produciría una subordinación de derechos y de la autoridad.

Este es el significado que adquiere la concesión del Breve de millones en 1591 por Gregorio XIV a Felipe II ${ }^{85}$. En él la plenitudo potestatis papal se vincula con los derechos del estado eclesiástico a través de un privilegium de servicio al monarca temporal, en paridad con el estado secular; adquiriendo también el significado de libertad jurisdiccional. No obstante las condenas contenidas en la bula In coena Domini con respecto al recurso de fuerza, éste era ejecutable mediante una relación de servicio al «rey natural» ${ }^{86}$, bien en materia de retención de bulas bien en virtud del recurso de amparo, procediese éste de un seglar o de un eclesiástico ${ }^{87}$. Merced a la constitución de la immunitas, la ejecución, a través de ella, de la bula In coena Domini no podía anular la condición legal del recurso de fuerza.

82 «...procurando sua Stà continuamente in ogni maniera che può, sequendo il pastoral offitio suo, di emendare gli abusi, et introdurre nei popoli quella cristiana disciplina et religione che si conviene, si come in Roma et in altre città non cessa di fare particolari processioni, seguendo le occorrenze et bisogni loro, cosi ove gli abusi sono più sparsi et universali non può mancare di fare ancora ordini generali che provedano sufficientemente ad ogni luogo...", «Risposta alla Instruttione data al Sor. Commedore...", op. cit., fol. 374v.

as Vid. Prool, P., I/ sovrano pontifice, Bologna, 1982, p. 73. Beauchet, "Origenes de la jurisdiction eclésiastique", Nouvelle Revue Historique (1883).

84 Así, el Patriarca de Alejandría impulsará la confección de una escritura, redactada por Paolo Beni en 1594, en la que se defiende la autoridad eclesiástica de la intercesión de Bulas y provisiones apostólicas practicadas por parte del Consejo Real y Chancilierias, apoyándose no sólo en la Bula In coena Domini, en el derecho canónico, o en la autoridad del Concilio de Trento, sino en las mismas fuentes en las que se apoyaba el ejercicio del recurso de fuerza: el derecho castellano. Dicho escrito aparece bajo el título, "Responsum iuris circa interceptionem literarum Apostolicarum quo ostenditur usum intercipiendar literar Apostolicar esse contra leges Regias provintiae Castelle sacros canones, Concilium Tridentinum, et Bullam Coenae Domini", ASV, Fondo Borghese, III, 23, fols. 505r-521v. Vid. Prod, P. , II sovrano pontifice, op. cit., p. 131.

${ }_{85}$ "Breve de Gregorio XIIII. En que manda al estado eclesiástico, que contribuya en los millones por seis años», B.A.V. Stamp. Barb. C.II 18.

86 Catalano, G., op. cit, p. 32.

87 En una carta de julio de 1581 , se lamenta el Nuncio del hecho de no poder «...evitare di non mandare li processi al Conseglio à querela delle parti col ricorso della forza, et questo per essere il rimedio del canone, et delli leggi di questi Regni che tanto antica prattica, et cosi frecuente che da tutti li tribunali principali del Rè se tiene per punto di rebbellione à un certo modo il metterlo in compromesso, come giurisditione del Re alla difesa da suoi vasalli, et perderiano più presto questi tribunali ogni gran cosa, che spogliarsi di tal prehemenenza...", ASV, Fondo Borghese, I, 94-96, fols. 9v-10r. 
Como sanción de este privilegium de servicio y como expresión de un cuerpo legal de «reglas seguras y sustanciales» pueden considerarse las apelaciones, en la correspondencia entre la Santa Sede y la monarquía, a la libertad de la Iglesia, la inmunidad, o a la autoridad del Concilio universal; principio este último que se integra en el deber de consilium que la autoridad espiritual compartía con los príncipes temporales, que lejos de constituirse contra el papa, se erige en legitimador de las decisiones pontificias ${ }^{88} \mathrm{y}$, por tanto, frente a los príncipes católicos. Como conscuencia, el significado que adquiere la publicación de la bula In coena Domini por Pio $V$, o por sus sucesores ${ }^{89}$, se inserta en la formación de regulis iuris sobre cuya base se constituye un discurso entre estados y cuerpos, en sintonía con otras disposiciones pontificias como la publicación de la bula Cum alias en 1591 por Gregorio XIV ${ }^{90}$, en conformidad con los presupuestos tridentinos ${ }^{91}$, o el privilegium immunitatis ${ }^{92}$. Frente a estas reglas se ajusta la ley de fuerza. Su función no era ejecutar, sino servir de defensa frente a cualquier innovación o deformación del derecho, es decir, se constituia como garantía de la justicia legal y con ella de la legalidad ${ }^{93}$. Con la inmutabilidad del derecho, quedaban protegidas la ley y la costum-

38 El nuncio se apoya en dicho consilium para desautorizar las pretensiones de los magistrados hispanos de legitimar la desobediencia al pontífice. Así se queja de "Che sia permesso alla forza secolare d'impedire l'obedienza delle constitutioni Pontificie fatte con maturo conseglio à benefitio della Chiesa universale et ratificate doppò molte consulte et contradittioni», Memorial del Nuncio, Patriarca de Alejandría, para Roma, Cardenale Aldobrandino, enviado con carta de 6 de diciembre de 1597, ASV, Fondo Borghese, III, 81a, fols. 574r-584r. Vid. MAZzONE, U., "l dibattiti tridentini: tecniche di assemblea e di controlo", /l concilio di trento e il moderno, op. cit., pp. 101-136.

${ }^{89}$ A las publicaciones de Pio $V$ se suman las de Gregorio XIII en los años 1572, 1573, 1575, 1578, 1580. Sixto V en 1586. Clemente VIII en 1592 y 1600, LópEZ, J.L., Historia Legal.., p. 10.

90 Dicha bula confirmaba otra de Inocencio III de 1098, sobre la concesión de jurisdicción privativa al clero en materia del privilegio del foro, [CONTIN, T.A.], Riflessioni sopra la Bolla In Coena Domini. Venezia, 1769, p. 154. Vid. Pastor, I., Storia dei Papi dalla fine del Medievo, vol. X. Storia del Papi nel periodo della Riforma e restaurazione cattolica. Sisto V. Urbano VII, Gregorio XIV e Inocenzo IX (1585-1591). Roma , 1955, pp. 565-566.

91 Vid. PÉrez Prendes, J.M., “El tribunal eclesiástico (Sobre el aforamiento y la estructura de la Curia diocesana de justicia)" en, Instituciones de la España Moderna, op. cit., pp. 143-169.

92 Vid. Catalano, G., op. cit., p. 3, n. 8.

93 Pío V sobre este punto advierte a Felipe II que «...l'intentione di Sua Stà. non è stata d'indurre li popoli à sollevatione alcuna, la quale più tosto può nascere da eccessive gravezze imposte, che da questa Bolla; Ma è stata di mostrar la via di conservar in quiete et Religione le Città et avertire à chi tocca dell'offitio suo, et però quando Sua Sta. sia certificata che alcuno su Prelato habbi cercato d'interpretare, o essequire altrimenti la intention sua, non mancarà fargli la debita provisione». A ello aún añade «Et perche sua Stà. tiene per fermo tutto questo esser molto alieno dalla pietà et Religione d'un Re tanto Catholico, come è la Mtà. sua, spera ancorche se vi sarà qualche cosa che habbi bisogno di esser ridotta à buona norma et regola sua Mtà. habbi da esser quella medesima che la procuri...", "Risposta alla Istruttione data al Sor. Commedore. maggiore, ambtore. del sermo. Rè Catholico", ASV, Misc. Arm. I-XV, Arm.II, vol. 102, fols. 374r-382r. Vid. SERRANO, L., op. cit. T. III, pp. 1-19. 
bre canónica de la monarquía hispana ${ }^{94}$, los lazos de unión entre el «príncipe cristiano» y el clero, pero ello con arreglo a los principios del «reino natural». Esto era posible porque se imponía la preeminencia de la costumbre - fuente de la que también bebía el papado-, como signo de inmutabilidad, sobre la potestad legislativa ${ }^{95}$. La bula no podía erigirse mediante una renovatio jurídica en lex ejecutiva expresión de la plenitudo potestatis papal. La consecuencia es que no podrá revocar ni el privilegio ni la costumbre, pues su irrevocabilidad era el principal impulso de la inmutabilidad ${ }^{96}$. Como acto espiritual, expresión del derecho pontificio, la bula In coena Domini tampoco podía quitar la "defensión natural" ni los casos en donde había "verdadera violencia", es decir, no podía eludir el derecho natural ${ }^{97}$; pues a...no concede fu Santidad privilegio que perturbe el orden judicial, y que perjudique a la parte agraviada" ${ }^{98}$. El recurso de fuerza como expresión de una razón natural y jurídica no pudo ser alterado ni por el valor general de las disposiciones pontificias, como la bula In coena Domini, ni con una ratio espiritual constituida a partir de preeminencia de la reformatio sobre la inmutabilidad o de lo espiritual sobre lo temporal, puesto que se erigía como afirmación de la inmutabilidad de lo natural como principio no jurisdiccional. De esta forma se evitaba la constitución de una potestas iurisdictionis espiritual universal como superioritas

94 Catalano, G., op. cit., p. 33.

95 En palabras de Juan Cabasucio: "Es pues la regla del derecho, y la mas constante proposicion en estas materias, que el mejor Intérprete de las Leyes es la misma costumbre", op. cit., por Juan Luis López, op. cit., p. 105. El propio Juan Luis López aduce: “...el poco escrupulo, que puede causar la publicacion de esta Bula á los Principes, y Ministros seculares, en todos aquellos puntos pertenecientes á las regalías y Reales preeminencias de S.M. adquiridas con tantos, y tan grandes méritos suyos, y de sus Reynos, y vassalios, por Privilegios de la Santa Sede Apostólica, por costumbres, y possession inmemorial, legitimamente prescripta, ya aprobada con el tácito consentimiento, y aprobacion de los sumos Pontifices, que no enflaquece, ni deroga, la publicacion de esta Bula de la Cena, aun en aquellos reinos y provincias a donde se usase publicarla», p. 102. A esto aún añade: “...lo que enseñan grandes autores es que siempre y quando se publique alguna ley, se continúa la costumbre, como en nuestro caso se entiende estár suspendida la obligacion de la ley derogatoria de la costumbre contraria, por tolerarla el legislador, y no castigar a los Transgresores", p. 103. Contemporáneo de Juan Luis López, B. Gallego de Vera sostiene que "la costumbre es optima legum interpres", Explicación de la Bula de la Santa Cruzada. Madrid, 1652, fol. 17v. Cfr. Lalinde Abadia, J. "Perspectiva europea de la monarquía hispana", Anuario de Historia del Derecho Español, LVIII (1988).

96 PASTOR, L., Storia dei Papi. Dala Fine del Medievo. Storia dei Papi nel periodo della Riforma e restaurazione Cattolica, op. cit., p. 288. Vid. Philippson, M., op. cit., p. 134.

97 Asi lo sostiene Manuel Rodriguez Lusitano en su obra: Summa de casos de conciencia con advertencias muy provechosas para confesores con un orden judicial a la postre, en la cual se resuelve lo más ordinario de todas las materias morales. Salamanca, 1597 , p. 428.

98 Ibid. p. 220. 
omnímoda e indivisa ${ }^{99}$. La división de la potestas permanece como freno del señorío, y como principio básico del orden jurídico fundamentado en relaciones de lealtad ${ }^{100}$. Por medio de la ley de fuerza se constituía una "obligación natural» exenta de lo espiritual ${ }^{101}$. Frente a la tradicional legitimación pontificia, surge la obediencia política, de naturaleza temporal y separada de razones religiosas, como expresión legal del príncipe soberano ${ }^{102}$. Esto quiere decir que el vínculo de lealtad y de obediencia es inalterable por causa espiritual, mientras que el vínculo jurídico se revela como el único susceptible de obligar en justicia y en conciencia, que denota libertad por cuanto supone la sanción de derechos inalterables.

Los pontífices y la propia Nunciatura en su ansia de dotar de razones a un poder espiritual preeminente en el universo de conceptos que en-

99 «Sed universi orbis ecclesia, cuius quidem nomen non divisionem, sed unionem et concorduam significat", CORDOBA, F. DE, Annotationes Catholicae in religion os articulos à sectarius controversos, quibus candidus lector dogmatum disidia haud difficile fedare poterir. Colonia, 1572, p. 297, y en general el cap. 28 "Universalis unitas est legitima ecclesiae nota", p. 296.

100 Dicho concepto lo encontramos expresado como sigue: “...la división de las cosas fue justamente introducida porque el dominio y señorio dellas no estuviesse pro indiviso y fuese causa de menosprecio como sucede en las causas comunes...", "Epítome del artículo propuesto con la primera cuestión sobre los derechos y razones que tiene su Majestad para conocer en las causas eclesiásticas por vía de fuerza». [memorial anónimo del reinado de Felipe III], BAV Barb. Lat. 2648, fol. 283r. Dicho memorial lo recoge HAROLD JONEs, G., Hispanic manuscripts and printed books in the Barberini collection, I Manuscripts. Città del Vaticano, BAV, Studi e testi, 280, 1978.

101 Con respecto a la prioridad de la obediencia natural sobre la obediencia al pontífice, el nuncio escribe a Felipe II: “Doppo haver scritto a V. Mtà l'altro giorno per mia scusa e giustificatione hà venuto a mia notitia, ch'il fiscal di V. Mtà intenta una novità contro la Sta. Sede Apostolica la piu pregiuditiale et scandalosa che mai si sia intesa in questi Regnii et è che si commandi in nome di V. Mtà che non siano ricevute lettere missive et Brevi di S. Stà et suoi Ministri, ò suoi Nuntii, et che non siano obbedite se prima non sono essaminate et viste nel Conseglio. Questo motivo non posso credere che possa piacer a un'animo cosi pio et cosi Cattolico, come è quello di $V$. Mt. perche non serve ad altro ch'a togliere affatto la libertà della Chiesa di Dio, violare il giuramento che gl'ecclesiastici danno al Papa et snervare et annihilare l'auttorità Pontificia in questi Regni, et far manifesta alli naturali et sttranieri in tempi pieni di miserie. La desunione del Conseglio di V. Mtà con li Ministri di S. Stà. Perche mettendosi in essecutione novità cosi pernitiosa et importuna II Papa andarà pensando à rimedii violenti di dichiarationi et di revocationi de gratie, come si costuma di far nella Corte di Roma, quando si ferisse nel'unno l'obeddienza di S.Sta, come si fà in questo caso, et si viene poi da tutte le parti à termini, che non ricevono accomodamento, supplico con ogni humiltà V. Mta. che sia servita di non dar luogo à innovationi in tempo, che S.Sta. non pensa ad altro, che al servitio et conservatione della sua potenza...", 1597, ASV, Fondo Borghese, III, $81 \mathrm{a}$, fols. $476 \mathrm{v}-477 \mathrm{r}$.

10.2 El concepto de obediencia política temporal, y la práctica de la simulación por razón politica, lo vemos expresado en una carta de Alejandrino a Castagna de 6 de marzo de 1567, con motivo de la guerra de Flandes, Serrano, L., op. cit., T. If, p. 53. Vid. LyNCH, J., op. cit., p. 34. Sobre la evolución de esta política vid. CÁRCELES DE GEA, B., "Ragione iuridica, ragione politica dell' immunitas ecclesiastica nella Corona di Castiglia nel ' 600 ', seminario impartido en la Escuela Española de Historia y Arqueologia del CSIC en Roma, el 18 de noviembre de 1996, y en el Istituto Italiano di Studi Iberici en Roma, el 10 de diciembre de 1997, Annali dell'Istituto Storico Italo-Germanico in Trento (1998). 
traban a formar parte de la legitimación de la auctoritas, lo hacen en numerosas ocasiones valiéndose de la immunitas, pero su sanción legal lo será en tanto que razón jurídica, no meramente espiritual ${ }^{103}$. Este privilegio no sólo implicaba al estado eclesiástico en su condición de servidor de los príncipes temporales, sino, también y, como consecuencia, al monarca, a través del vínculo jurídico establecido entre el clero y un "príncipe cristiano». Las declaraciones expresas de Felipe II a favor de la inmunidad eclesiástica, y el mismo recurso a Gregorio XIV para obtener el indulto papal para la percepción del servicio de millones, mientras disiente de las restricciones a los príncipes temporales en materia fiscal declaradas por la bula In coena Domini, prohibiendo su publicación ${ }^{104}$, nos confirma por la parte regia, que el refrendo de la autoridad eclesiástica que vincula la monarquía con el papado se produce, con la sanción de la libertad de la Iglesia y de sus derechos jurídicos, mediante el servicio al «rey natural», es decir, de la lealtad al rey. A partir de este vínculo se constituye la "obligación en conciencia", como razón jurídica inductiva, de un "príncipe cristiano", y no merced a un vínculo espiritual, como obligación moral, en tanto que "rey católico" con la potestas del pastor universal ${ }^{105}$. La obediencia al papa como "rey católico" exento se constituye en un acto de lealtad. Con arreglo a este principio, la convergencia en la sanción del privilegio, de lo común legal, es lo que va a obligar a la monarquía y al papado, a la monarquía y a sus súbditos naturales y, consecuentemente, al papado y al estado eclesiástico. Dicha convergencia es la única que constituye "obligación en justicia", y en ésta última es en la que se asienta el principio de legalidad según un concepto de justicia legal, integrado en una razón de defensa como atributo del rey ${ }^{106}$. Felipe II contradice la bula In coena

103 Vid. Downs, J.E., op. cit.

104 De esta forma se expresa en 1568 con motivo de la publicación de la bula In coena Domini por Pío V, «Instruttione di quanto voi it comendator maggiore di Castiglia del nostro Consiglio di stato, et nostro Ambassator in Roma havete da fare in quella Corte", op. cit., fols. 366r-373 (bis). Pio $V$ habia añadido en la publicación de la Bula en 1567 la palabra Gabelas a la palabra peaje y también la palabra aumentan, lo que sería contradicho por Felipe II. En concreto la Bula reza como sigue: "A los que en sus tierras imponen, 6 aumentan nuevos peajes, o gabelas o piden que se impongan, y aumenten las prohibidas fuera de los casos permitidos por derecho o especial licencia de la Sede Apostólica", Juan Luis LóPEZ, op. cit., pp. 16-17.

105 Cfr. Prodi, P., “ll concilio di Trento...", op. cit.

106 Tal concepto de justicia legal y de defensa los encontramos expresados como sigue: «Las leyes justas que miran al bien publico de eclesiasticos y seglares son leyes de caridad y justicia legal que defienden al agraviado y procuran la paz publica contra qualesquier opresion del proximo y perturbadores de la publica tranquilidad...", "Epitome del articulo propuesto con la primera cuestión sobre los derechos y razones que tiene su Majestad para conocer en las causas eclesiásticas por vía de fuerza», op. cit. fol. 280 r. 
Domini en lo que ésta pudiera tener de menoscabo de la «preeminencia real» ${ }^{107}$, como consecuencia de su constitución en potestas espiritual por un acto de fuerza - de agravio-, entendido como un acto espiritual ejecutivo, no sujeto a aprobación, contra la autoridad real ${ }^{108}$, no como expresión del privilegio, o en su constitución de servicio en el reino natural; es decir, no mientras se imbrique en la legitimidad y legalidad del "reino natural" y de lo temporal. La sanción de la bula In coena Domini que, de hecho, lleva a cabo Felipe II con la solicitud del indulto papal en 1591 para la contribución a los millones, lo confirma ${ }^{109}$.

Como consecuencia de la dependencia de la autoridad con respecto al privilegio, aunque el recurso de fuerza no pudiera apoyarse en concesiones de la Santa Sede, como alegaron los pontífices ${ }^{110}$, Felipe II pudo apelar al «privilegium justo" por razón de dignidad y por la "naturaleza de ser rey" 111 - de nuevo separado de la legitimación pontificia-como premisa para la constitución de la auctoritas, inserta en una legalidad que se servía de otras razones legítimas y que no podía ser en ningún caso alterada

107 ALDEA, Q., op. cit.

108 Felipe II, sobre los capítulos de la bula In coena Domini, se inclina por mantener una estrategia de moderación sin provocar la emisión de censuras, instando al duque de Alcalá, virrey en Nápoles, a que se mantenga «...con el ánimo quieto, y no incurrir con descuido en las censuras de la Bula in Coena Domini", para a continuación encargarle que tenga "...cuidado de favorecer la jurisdicción eclesiástica, y de no venir contra ella, en cuanto no fuere contra preeminencia real...", 24 de marzo de 1567, BAV, Barb. Lat. 5.389, fol. 56r. Sobre este conflicto, Juan Luis LóPEz, op. cit., pp. 58 ss. Por otro lado, como acto de fuerza en materia jurisdiccional califica Felipe II la Bula, "Instruttione di quanto voi il Comendator maggiore di Castiglia del nostro Consiglio di stato, et nostro Ambassator in Roma havete da fare in quella Corte», op. cit.

109 Por tanto, los capitulos de Cortes de 1593 no derogaron ni la inmunidad ni la jurisdicción eclesiástica. Cfr. E. Hinojosa y Naveros, op. cit., p. 355. Vid. Covarrubias y Leiva, D. De, Variorum ex lure Pontificio, Regio et Caesareo Resotulionum. Salamanca, 1561, pp. 163v-164v.

110 “...sua Stà. non ha notitia d'alcuni privilegii, ne di tali ragioni, la qual Mtà. sua potrà com mandare alli suoi Agenti, che li mostrassero, essendo di manifestissima ragione, che chi allega, o si vuol servire di quei privilegii, deve mostrarli. Et tanto più che N.Sre. e, solo et legitimo interprete de privilegi, che si pretendono da suoi Predecesori», «Risposta alla Instruttione data al Sor. Commedore. maggiore, ambtore. del sermo. Rè Catholico", op. cit. Así lo recoge J. Ceballos en su obra Tractatus de cognitione per viam violentiae in causis ecclesiasticis et inter ecclesiasticas. Toledo, 1618.

111 En un memorial, que se dio a Felipe II, fue visto por el Consejo de Castilla, y que se entregó a una junta a la que se cometió la resolución del conflicto surgido alrededor del recurso de fuerza, enviado por el Patriarca de Alejandría al cardenal Aldobrandino, se sostiene que: «...li secolari non potevano far questa legge senza privilegio de sommi Pontifici, il che non si mostra d'haver ottenuto, anzi dicono, che il Re lo fa come Re et signore, et non per vigor di privilegii, li quali quando anco vi fussero cessa la ragione in che si fonda detta legge essendo hoggi superior in questo Regno, che è il legato, et quando non vi fusse legato in tal caso si deve recorrer al Papa perche vi proveda, et non le leggi senza autorità...", ASV, Fondo Borghese, I, 772, fol. 903. 
sin dañar el principio de autoridad ${ }^{112}$. Hemos de tener presente que el recordatorio que Felipe II hace con respecto al consentimiento tácito de los pontífices del recurso de fuerza, alude a una obligación legal del papado y no a su legitimación.

La preeminencia del privilegium jurídico como nexo legal se explica porque excluye la posibilidad de que la auctoritas pudiera ser subordinada, ni siquiera por motivo de una ratio espiritual jurídicamente inductiva ${ }^{113}$. La constitución de esta ratio obliga al pontífice y al monarca ex officio ${ }^{114}$; una obligación que se materializa también en lo temporal. Si la razón de conciencia de un "príncipe cristiano» ${ }^{115}$, como protector de los sagrados cánones, se constituye como un acto de sanción de la missio espiritual, como superioritas, de la Iglesia y de lo sobrenatural, el correspondiente ejercicio de la jurisdicción temporal, según los argumentos de Felipe II, dirigido "...al servizio di Dio, et bene della Chiesa et benefitio publico, de donde depende la conservatione de nostri stati, et della quiete et pace publica" ${ }^{116}$, le garantiza sus derechos y privilegios temporales en virtud de la misma ratio. Una preeminencia que se sostiene gracias a la supervivencia conceptual de lo temporal. La vocación particular del papado, como monarquía, en lo que tiene de exaltación de una potestas temporal legítima ${ }^{117}$, con la consideración de Cristo, como rey temporal, en beneficio de un fin último espiritual, o en función de una misión renovaturus mundum, lo sanciona ${ }^{118}$. Al constituirse el servicio a Dios en

112 Identificado por el cardenal Aldrobrandino con derechos y razones regias (Carta del cardinale Aldobrandino al nuncio, de 20 de abril de 1597, op. cit.), no llegará a evocar la regalia del monarca en función de la potestad real, sino en su acepción, que en la siguiente centuria Juan Luis LóPEz llamará negativè (Aunque con referencia a los fueros de Aragón, como defensor de la jurisdicción real, Juan Luis López considera a esta regalia negativè como un límite al poder real, De origine lustitiae, Madrid. 1678, pp. 26-27. Según esta acepción la regalia era asumida por los tribunales reales, especialmente el Consejo de Castilla, como exponentes del vínculo de fidelidad entre el rey natural y sus súbditos. Vid. CovarRuBIAS, J., op. cit., p. 151. También, el CONDE DE LA Cañana, op. cit. Cfr. Maldonado, J. op. cit., p. 306.

113 CORTESE, E., La norma juridica, 1962-69, vol. I, p. 293.

114 Vid. Bouwsma, W., "Venice, Spain, and the Papacy: Paolo Sarpi and the Reinaissance Tradition", The late italian reinaissance (ed. E. Corchrane). N. York, 1979, p. 374. C. Continuo, " "ll principe, il sistema delle virtù e la costruzione di una "Bueona Società"», I tempi del Concilio. Religione, cultura e società nell'Europa Tridentina (eds. C. Mozzarelli, D. Zardin). Roma, 1997, pp. 286-287.

115 Dicha razón de conciencia interviene en donde se tratan razones de estado. Anónimo, "Oratione al rè cattolico. Nella morte d'Enrico Quarto rè di Francia", ASV, Misc. Arm. I-XIII, Arm. III, 13, fol. $284 \mathrm{r}$.

116 "Instruttione di quanto voi il Comendator maggiore di Castiglia del nostro Consiglio di stato, et nostro Ambassator in Roma havete da fare in quella Corte", op. cit.

117 Vid. ProdI P., II sovrano pontifice, op. cit.

118 Lorenzo DE ZAMORA, así lo argumenta: “...quanto el señor entro en la santa ciudad de lerusalen (como refiere San Mateo) fue por ventura para dar a entender, como era verdadero rey, $y$ Emperador suyo. Y lo que más es no solo le confesaron por Rey temporal en esta ceremonia, sino por verdadero Dios: porque antiguamente en reconocimiento de la deidad se hazia ello", Monar- 
lo temporal, adscrito a un orden natural, con independencia de la potestas indirecta papae in temporalibus, se legitimaba su libertad. La publicación de la bula In coena Domini por Pío $V$ o por sus sucesores como un acto espiritual en un gesto de activación de la libertad eclesiástica como medio para cumplir su missio universal, lejos de ser constitutiva de una ratio espiritual asumida por la Iglesia, susceptible de subordinar en conciencia y en derecho a un "rey católico", también se imbrica con las fuentes de legitimación en las que se fundamenta la elaboración conceptual de un rey "Vicario de Dios" en lo temporal. Al adscribirse el servicio a Dios a Felipe II, rey temporal y en lo temporal, no puede subordinar a un rey "que no conoce superior en lo temporal», y, por tanto, a partir de esta subordinación anular la independencia, libertad, ejercicio y derechos del poder temporal. Dicho ejercicio es privativo lo que le permite la constitución de conceptos específicos y de la razón de un servicio temporal propio ${ }^{119}$. Como consecuencia, la dualidad de un rey temporal y católico, lejos de arrogarse la ratio católica ${ }^{120}$, permite que la razón de estado se legitime y conceptualice en la actuación del rey defensor de sus súbditos, príncipe temporal. Un "rey católico" se constituye por relación a la exención de lo espiritual -con las palabras de Felipe II, «independiente en lo temporal»-, no en función de su señorío sobre la religión. Al no ser apropiada, la ratio católica no desvirtuaba su finalidad en la respublica christiana, manteniéndose indemne el servicio espiritual privativo del estado eclesiástico. Esta doble conditio del monarca se pone al servicio de una relación que necesariamente tiene que basarse, no sólo en la equiparación, independencia y separación de la autoridad, sino en la constatación de un servicio a Dios que

chia Mysticia de la Iglesia, hecha de Hieroglificos sacados de humanas y divinas letras. BarceIona, 1608, pp. 33-34. Vid. BAÑES, D., op. cit., pp. 83 ss. DOMINGO DE SOTO, aunque le niega el poder temporal a Cristo, en la misma linea pasa a legitimar dicho poder por fines espirituales: “....solamente tuvo (Cristo) potestad sobre las cosas temporales en orden al fin espiritual, o sea, en orden a la redención”, Relección..., op. cit., p. 161. Vid. Frutos VALIENTE, F. ${ }^{\circ}$ " "Doctrina de Vitoria sobre la realeza de Jesucristo", Anuario de la Asociación Francisco Vitoria (1930-31), III, p. 95.

119 Vázquez de Menchaca lo confirma: «...cuando (las leyes) son instituidas por quien sólo tiene jurisdicción temporal, entonces las mismas leyes son temporales y producen acciones temporales", op. cit., p. 133.

120 En caso contrario, «...aspirando il Rè di Spagna à tanta signoria, ha bisogno di far Religion nuova, il che gl'è contradetto da Dio, e dalla ragion Politica", además, "Si come prova con ragion Divina, adesso provo con ragion Politica che in Christianità, non vi può essere Monarchia Universale, che non sia, o dependente dal Papa, perche in vero dovunque si ritrova un Principi, il quale habbia un'altro sopra di se, che regna con la Religione, non che con armi, come è il Papa, già mai può arrivare alla Moriarchia Universale, perche ogni cosa, che tenta li vien' rota in mano del superiore, poiche la religione, ò vera, ò falsa sempre ha vinto, quando ha havuto credito, perche lega gl'animi, onde perdono i corpi, e le spade e le lingue, che sono strumenti d'imperio", fol. 20v, "Discorso sopra la Monarchia di Spagna», [anónimo], BAV, Barb. Lat. 5198, fols. 21v-22r. Hay copia en ASV, Fondo Borghese, I, 308. 
dota a lo temporal de entidad suficiente para no ser superado frente a la preeminencia no sólo del poder sino en general de lo espiritual ${ }^{121}$, como lo había venido siendo considerado durante la Edad Media ${ }^{122}$. Una supremacía que la doctrina fundaba en la jurisdicción indirecta del pontífice sobre los príncipes temporales ${ }^{123}$; teoría que entonces encontró cumplida acogida en Roberto Belarmino ${ }^{124}$, que fue a menudo puesta en práctica por los pontífices con excomuniones y censuras ${ }^{125}$, y que no dejó de preocupar al propio Felipe II hasta el final de su reinado ${ }^{126}$. A ello se añade la preferencia dada en el ámbito espiritual al mundo terrenal con la cura animarum. Con la afirmación del poder temporal en beneficio o en armonía, por sí, con el fin espiritual, de hecho, se anulaba la potestas indirecta del pontífice para entregársela al príncipe secular, "rey católico» ${ }^{127}$. Lo temporal adquiría «eficacia» de razón de forma indirecta, pero al no serlo por medio del poder espiritual, en una relación dual, también per se ${ }^{128}$.

La garantía legal de esta representación conceptual se llevaba a la práctica con el recurso de fuerza, bajo cuya determinación se decidian los

121 Esta idea la vemos legitimada en Domingo de Soto: “Aunque el fin próximo del Jefe de la Nación sea la tranquilidad de la república, sin embargo el fin último es la bienaventuranza. Por tanto con sus leyes, en virtud de la autoridad recibida del cielo, puede obligar en el fuero supremo. Deduzcamos por consiguiente que, aunque no sea herejía manifiesta negar esta autoridad y eficacia a las leyes civiles, como lo es negarlas a las eclesiásticas, sería temerario y contrario al sentir unánime de los doctores, que merecen más llamarse de esta manera", De la justicia y del Derecho. Madrid, 1967, p. 52.

${ }_{122}$ Gulraud, J., op. cit. El hecho de que inicialmente fuera la autoridad espiritual la que tenía el derecho del recurso de fuerza sobre la actuación de los jueces seculares, en conformidad con

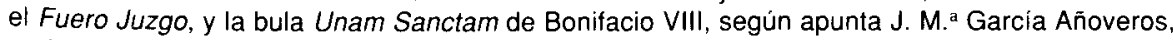
sería indicativo de la subversión que se ha producido con la emergencia del poder temporal, $L a$ Monarquía y la Iglesia en América, 6. La corona y los pueblos americanos. Valencia, p. 86.

${ }_{123}$ Una facultad que era algo más que teórica para los pontífices. En despacho del nuncio de 26 de julio de 1572, afirma: «...S.S. me dijo muchas veces fuera de la instrucción, haberle dado, no sólo por honrar á un Príncipe tan benemérito, sino para recobrar el ejercicio interrumpido, usar de la posesión y traducir en hechos la suprema autoridad que tiene el Vicario de Cristo sobre todas las potestades terrenas y la facultad de honrar ó deprimir á los Principes según sus méritos", E. Hinojosa y Naveros, op. cit., pp. 207-208.

${ }_{124}$ Como ya destacara Eduardo Hinojosa y Naveros, op. cit., p. 318. La obra de RobERTo BE. LARMINo es: Politiari ex Societate lesu. De controversiris fidei adversus hujus temporus Haereticos, cuyos tres tomos se publicaron en los años, 1581, 1582, 1592.

125 Se puede, incluso, llegar al extremo de declararse, como lo hizo Pablo IV, "caducidad de dominio", o absolución del juramento de fidelidad del súbdito, Cánovas del Castillo, A., op. cit., parte II, p. 447 .

126 Asi se lo expone a su hijo, el fututro Felipe III, en unos consejos para gobernar, el Conde Atares, op. cit., p. 561 .

${ }_{127}$ Cfr. IZAGA, L., "La soberanía civil según Suárez», Razón y fe, 124 (1941), p. 317.

128 FranCISCO FRUTOS VALIENTE recoge en su trabajo sobre Vitoria esta idea: "Corresponde, pues, a Cristo la eminente posesión de la realeza de todos los reyes y el poderío de todos los poderes, y esto no solo indirectamente, en orden a lo espiritual, sino directamente per se", op. cit., p. 98 . 
casos en los que los jueces o tribunales espirituales conocian de una causa profana no sujeta a su jurisdicción, anulando la jurisdicción temporal del pontífice en orden a lo espiritual ${ }^{129}$, pero también la del clero, extremo que estaba además prohibido por la legislación ${ }^{130}$. Ello era especialmente importante en los casos frecuentes de competencias ${ }^{131}$. Además, la jurisdicción civil ejercida por el clero no podía separarse del "rey natural" de quien emanaba toda potestad temporal ${ }^{132}$. En cualquier caso se abortaba el vínculo entre el clero y el pontífice por causa temporal y que la potestas indirecta fuese jurídicamente factible. Configurado como instituto de legitimación, el "reino natural» permite la división de la autoridad como principio jurídico, no filosófico teológico. Por consiguiente, con la constitución de un «rey católico» temporal, pero a través del orden natural, se producía la exaltación, libertad e inmutabilidad de lo temporal, no de lo espiritual.

La ratio espiritual y la ratio temporal aseguran al monarca la libertad de una especificidad y trascendencia de lo temporal y de las leyes civiles ${ }^{133}$. Mientras que el vínculo entre el clero y el monarca como «príncipe cristiano" es de naturaleza jurídica. Así, el rey sanciona la immunitas como razón espiritual directe, pero a la que se obliga legalmente merced a su función jurídica. Gracias al servicio espiritual del clero, el concepto jurídico

129 Y ello no obstante que nos encontremos con quien, corroborando la jurisdicción indirecta del pontífice, excluya estos casos del conocimiento por vía de fuerza: «...queda resuelto que el Papa tiene jurisdicción temporal en orden a las cosas espirituales y cesando esta causa eclesiásticos y seglares pueden ser defendidos por vía de fuerza et extraordinarie cognitionis por los jueces de su magd. que están deputados para conocer en semejantes causas", Aunque, más adelante, el autor de este discurso legitime la defensa natural en orden al bien temporal en la misma medida que el pontífice ejerce el poder indirecto, «Epítome del artículo propuesto con la primera cuestión sobre los derechos y razones que tiene su Majestad para conocer en las causas eclesiásticas por vía de fuerza", op. cit. fol. $276 \mathrm{r}$ y $287 \mathrm{v}$. La Nunciatura, por su parte, advierte que estas causas competen al Papa, entregándole la jurisdicción indirecta: «...questa controversia di giurisdittione non puo esser decisa se non dal Papa il quale solo può dichiarare et terminare li confini et llimiti delle due Giurisdittione conforme a quello che dispongono li Concilii, sacri canoni et consuetudini antiche approvate et che alcune opinioni che da persone appassionate in questo negotio sono tenute in Spagna non si possono sostentare in buona theologia frale quaii sono l'infrate", [Memorial del Nuncio, Patriarca de Alejandría, para Roma, Cardenale Aldobrandino enviado con carta de 6 de diciembre de 1597], op. cit.

130 Dicha legislación la recoge HERMAnN, Ch., op. cit., pp. 27-28.

131 Bruno, C., El derecho público de la Iglesia en Indias. Salamanca, 1967, p. 223.

132 Extremo que recoge Diego DE COVARRUBIAS, "De qué manera reside en el rey toda la potestas y jurisdicción de la república castellana", op. cit., p. 300.

${ }_{133}$ "...perche'in ogni cosa si vuol mescolar la ragione di stato, et pare alli Principi, o al meno alli Ministri temporali di far un grand'acquisto, quando trovono modo d'intaccare la giurisdittione et immunità ecca...", carta del cardenal Aldobrandino al nuncio, 16 de enero de 1595, ASV, SS. Spagna, 325, fol. 48r. Para Domingo BAÑES, "Potestas civilis ad gubernandam rempublicam habetur ex iure divino naturali», op. cit., p. 83. 
de respublica christiana permanece, pero no como concepto integrado en la «república temporal» ${ }^{34}$, lo que hubiera supuesto su subordinación a lo temporal, extremo que era conceptual y jurídicamente inviable. El concepto de respublica christiana se mantiene como una universitas superpuesta que, merced a la comunicación entre lo natural y lo sobrenatural, trasciende la «república temporal» 135 .

Puesto que un rey temporal católico no podía ser subordinado por causa espiritual, la irrealizable subordinación en derecho lleva a que el estado eclesiástico, estado secular, el estado real, y los distintos cuerpos del reino, participando de la misma dualidad como ratio conceptual, pero ordenados y vinculados en función de principios jurídicos, impida la dualización de la relación entre el poder espiritual y el poder temporal. Y ello no porque tal dualidad desaparezca, pues un "rey católico» no se hace sacerdos, ni jurídica ni conceptualmente ${ }^{136}$ : asume la dualidad de razones en corresponden cia con los demás estados. Lo que ha venido siendo considerado como cesaropapismo o ${ }^{137}$, más recientemente, como sacralización del poder ${ }^{138}$, en realidad, se refiere a la activación de una razón espiritual indirecte que anula la avocación de lo temporal por fin espiritual por el pontífice, no a ajercer jurisdicción o potestad sobre lo espiritual, ni a

134 Cfr. Hermann, CH., op. cit., p. 96. También, Reinhard, W., "Etat et Eglise dans L'Empire entre Réforme el absolutism» en, Etat et Eglise dans la genese de l'Etat Moderne. Madrid. 1986 , pp. 175-185.

135 Ello lo podemos ilustrar con MELCHOR DE AVILA, procurador de las Cortes de 1598 a 1601: “regno y rey para lo seglar y temporal son como cuerpo y cabeza místicos», citado por M.A. EchevarRía Baclgalupe, "Las últimas Cortes del reinado de Felipe $\|$ ", Estudios de Deusto, 71 , p. 349.

${ }_{136}$ Vid. SkInNer, Q., The foundations of Modern Political thought. The age of Reformation. Cambridge, 1978. Utilizamos la edición italiana, Le origini del pensiero politico moderno. L'età della Riforma. Bologna, 1989, p. 26.

${ }^{37}$ Como ya destacara en su día Luciano Serrano, contra la tesis sostenida por PASTOR, L., "Primeras negociaciones de Felipe II...", op. cit. También, Catalano, G., op. cit. Más reciéntemente, A. BORROMEO ha llamado también la atención sobre la necesidad de desterrar concepciones según las cuales Felipe II adoptó una posición de cesaropapismo frente al papado, revisando también las tesis de PASTOR, L. op. cit., p. 180; también, "La politica postconciliare di Filippo II e il primo concilio provinciale milanese del 1565", Studia Borromaica, n. 8 (1994), pp. 303- 337. Cfr. M. Philippon, op. cit.

${ }_{138}$ Vid. SCHмIтT, J.C., “Problèmes religieux de la genèse de l'Etat moderne», Etat et Eglise dans la genese..., op. cit., pp. 55-62. Esta idea se corresponde con lo que modernamente se ha venido en llamar Konfessionsbildung, introducido por ZEEDENN, E.W., Die Entsehung der Konfessionen. Grundlagen und Formen der konfessionsbildung. München/Wien, 1965, cuyo paradigma confesionalización fuese defendido por W. Reihnard en la revista Annali. SchiLLING, M., Religion, political culture and the emergence of early modern society, Leiden (1992). Aunque, en realidad, se trata de un concepto sociológico, que no histórico, formado por relación a otro concepto, cuyo significado debe circunscribirse a un momento histórico, como el de secularización (vid. infra). 
suprimir la identidad de lo temporal -como de la utilización de estos términos se desprende-, sino todo lo contrario, a obtener su valorización como ratio inductiva per se, pues lo que ocurre es que, lejos de ser constitutiva de lo sagrado, la jurisdicción indirecta se hace secular, en el sentido jurídico del término, dotando a lo temporal de total independecia con la exención. Por lo que, en vez de producirse una vinculación más estrecha entre lo temporal y lo espiritual, la exención hace posible la separación entre ambas potestades.

La permanencia de la dualidad conceptual que, al ser asumida por todos los estados y cuerpos, e integrarse en el orden natural, no puede establecer una relación de "dominio absoluto" de un poder sobre otro por razón de su especie temporal o espiritual, va a fundamentarse en la contravención como garantía de que los vínculos de lealtad se ordenen por razón jurídica y de la consiguiente división, también jurídica, de la autoridad.

Efectivamente, el protagonismo adquirido por el recurso de fuerza y por la bula In coena Domini durante el reinado de Felipe II en sus enfrentamientos con el papado hay que buscarlo, en gran parte, en lo que ambos instrumentos tenían de suspensión de la ejecución ${ }^{139}$. Alrededor de esta suspensión se dirime la disputa y se activan los instrumentos jurídicos a tal efecto. El recurso de fuerza se basaba en la contravención en conformidad con formas de actuación que llamaban a los fundamentos constitutivos del vínculo jurídico entre rey y súbdito en la Corona de Castilla, no a una supuesta relación dual entre el poder espiritual y el poder temporal. A las reiteradas apelaciones de Felipe II como príncipe temporal a Roma contra la bula, se suma la actitud de enconada defensa del recurso de fuerza, como expresión de las leyes y costumbres de la Corona de Castilla ${ }^{140}$, también en lo temporal, adoptada por el Consejo de Castilla en la corte, y por las Cortes con su publicación en los capítulos de $1593^{141}$. El hecho de

139 Con respecto al recurso de fuerza, el cardenal Aldobrandino advierte a los nuncios que, en realidad, su introducción se debía a su papel de retención de las disposiciones pontificias, cifre de 20 de diciembre de 1594, ASV, Fondo Borghese, II, 472, fol. 424r.

140 De esta forma lo establecía la Nueva Recopilación publicada por Felipe II en su ley 80 , título 5, libro II, como advierte Quintín Aldea al señalar que Felipe II considera el recurso de fuerza como «el más importante y necesario para el bien y quietud e buen gobierno de estos reinos". El rey afirmaba que le pertenecía "como rey y señor natural, por derecho y costumbre inmemorial, quitar y alzar las fuerzas, que hacen los jueces eclesiásticos de estos reinos en las causas de que conocen, sin el cual toda la república se turbaría y se seguirian grandes escándalos e inconvenientes", op. cit.

141 «Le cause generali per le quali pare male, et si può tener offesa S.S., et li suoi Ministri deile Capitoli Trenta sei, trenta setti, trenta otto, trenta novi, quaranta, et quaranta uno, delle Corte generale dell'anno 1588 publicate l'anno presente sono l'infrascritti», 1593, ASV, Fondo Borghese, III, 24, fols. $216 \mathrm{r}-218 \mathrm{r}$. 
que los obispos se negaran a publicar la bula In coena Domini en 1566 sin el permiso del Consejo Real, hay que entenderlo, no ya por las condenas que establecía en materia de retención de bulas y de Letras Apostólicas, puesto que los jurisconsultos se encargaron de anular esta eventualidad ${ }^{142}$, sino como un acto de la facultad de consentimiento necesario para la ejecución de la autoridad, es decir, en la anulación de un «acto ejecutivo" no sometido a aprobación ${ }^{143}$. Las bulas sólo podían publicarse, y se publicaban en los obispados, en tanto que «instrumento público» del privilegium del estado eclesiástico ${ }^{144}$, servidor no sólo del pontifice y de Dios, sino del príncipe secular. A través del vínculo jurídico entre el rey y el clero, como súbditos, el estado eclesiástico ejercía la facultad de aprobar y consentir previo a su ejecución también las disposiciones pontificias. En caso contrario, la bula In coena Domini se hubiera constituido en un «acto ejecutivo", lo que hubiera colocado al estado eclesiástico a merced de la plenitudo potestatis papal; pero también a merced de una relación dual entre la Santa Sede y la monarquía, dejando al clero indefenso en materia de inmunidad. De esta forma, la aprobación del clero, con una voluntas espiritual, en lo que, de hecho, supone la representación de la fórmula quod omnibus tangit, ab omnibus approbari debet, encontraba su aplicación en el servicio al "rey natural» ${ }^{145}$. Al garantizarse por este lado que los vínculos estuviesen sujetos a la contravención se obtenía una relación de obediencia y fidelidad - que denota el ejercicio de la voluntad y de la razóna la Santa Sede, tal y como se producía entre rey y súbdito. En caso de no aprobarse las Letras Apostólicas, se recurría al procedimiento propio de la constitución castellana, ad melius informandum, para obtener su revocación ${ }^{146}$. Ello sólo era posible como procedimiento legal, pues la obediencia al pontífice estaba constituida sobre la base de un vínculo jurídico, no me-

142 En efecto, los juriconsultos hispanos argumentaron que no era necesario rechazar la Bula puesto que sus disposiciones no negaban de forma expresa el recurso de fuerza. Extremo que ya fuera destacado por M. PHILIPPSON, op. cit., p. 150.

${ }^{143}$ "Si parla con poco rispetto delle censure della Bolla in Coena Domini la quale deve esser stimata perche contiene in offitio, et conserva unita al suo capo tutta la Republica Christiana, et è fondata nell' osservanza delli sacri canoni, et del Concitio di Trento" en, "Le cause generali per le quali pare male, et si può tener offesa S.S., et li suoi Ministri delle Capitoli Trenta sei, trenta setti, trenta otto, trenta novi, quaranta, et quaranta uno, delle Corte generale dell'anno 1588 publicate l'anno presente sono l'infrascritti», op. cit.

144 FUENTE, V. DE LA, op. cit., p. 25.

145 Cfr. Pérez Prendes, J.M., Las Cortes de Castilla. Barcelona, 1974, pp. 48 ss.

${ }^{446}$ "...ma solo nel decreto della ritintione, si dice che si ritegono per informare S.Bne...", “Instruttione d'alcune cose di Spagna in materia di giurisdizione per il Nuntio di Spagna» (1591), op. cit. Tal procedimiento lo vemos también conceptuado como consultetor, en el que no se procedia por vía de jurisdicción, según consta en una carta del rey al marqués de Alcañices de 19 de abril de 1580, Serrano, L., T. III, pp. LXV-LXVI. 
ramente espiritual. Que Felipe II acudiera al papa Gregorio XIV para obtener el consentimiento en la contribución al servicio de millones ${ }^{147}$, en 1591, como materialización de este privilegium, en conformidad con lo establecido en la bula In coena Domini - aunque esta bula condenase a quienes impusieran los mismos tributos a seglares y seculares ${ }^{148}$-, nos indica la existencia de una «obligación común» con respecto a una legalidad que no puede ser alterada por una de las partes, sino sólo con el consentimiento mutuo. La contravención se erige en garantía de este orden.

Frente a la ofensiva del papado en materia de retención de bulas experimentada en el siglo XVI con las sucesivas publicaciones de la bula In coena Domini, los predicadores conceden indulgencias con la Bula de Cruzada para absolver de las excomuniones infringidas por la Bula de la Cena, e impedir su ejecución, extremo que estaba cumplidamente legitimado por la doctrina ${ }^{149}$. Los intentos de Pio $\mathrm{V}$ de constituir una potestas universal in spiritualibus con la ejecución de la bula In coena Domini suprimiendo la Bula de Cruzada, o de prohibir la elección de confesor para los casos reservados, con el Concilio de Trento, al margen de las repercusiones pecuniarias ${ }^{150}$, tenía como objetivo impedir la contravención de la autoridad espiritual; pero ello no fue viable ${ }^{151}$. Pio $\mathrm{V}$, aunque pudo introducir algunas restricciones en materia de disciplina, tuvo que transigir y conceder la Bula de Cruzada, como sus sucesores. Que los obispos castellanos hubieran expedido la Bula de Hermandad en 1570 para suplir las ganancias de la Cruzada ${ }^{152}$, ante las reticencias de Pio V de concederla, es síntoma de que, también al margen de las consecuencias pecuniarias, la contravención y el privilegio, puesto que como tal se pueden conceptuar las indulgencias, van unidos a la constitución de la auctoritas del estado eclesiástico como dignitas pública.

147 Vid. LovetT, A.W., «The vote of the millones (1590)», Historical Journal, XXX (1987), pp. $1-20$.

148 Phillprson, M., op. cit., p. 144.

149 Vid. Gómez, A., Dilucida, vera et fidelis sanctae cruciatae Bullae explicatio. Compluti, 1563. p. 95. Gallego de Vera, B., Explicación de la Bula de la Santa Cruzada. Madrid, 1652, fols. 107r108v. Filguera, M.A. DE, op. cit. Tratado VII, Cap. VI, «De la absolución de las censuras, y casos reservados, que se concede en la Bula de la Ciuzada", p. 244.

150 Sobre este aspecto, Luciano Serrano ha destacado las pérdidas que la Cruzada tenía para la Santa Sede en jubileos particulares y limosnas, "Primeras negociaciones de Felipe II y el papa S. Pio V', Hispania, I (1940), p. 95.

151 Goñı Gaztambide, J., Historia de la Buia de la Cruzada en España. Vitoria (1958), p. 558 .

152 GoÑ GAZTAMBIDE, J., op. cit., pp. 588-589. También, "Los cuestores en España y la rega lía de indulgencias", Hispania Sacra (1949), pp. 3-43 y 285-310. 
La función que adquiere el recurso de fuerza y la Bula de Cruzada en materia de contravención no anula la que desempeñan la bula In coena Domini o la immunitas ${ }^{153}$. Su tarea no era anular la función jurídica, sino todo lo contrario, obligarlos a adoptar un comportamiento estrictamente legal. La contravención que se lleva a cabo de las armas espirituales, con la absolución de censuras, entredichos y excomuniones, mediente el recurso de fuerza, permite que el principio jurídico prevalezca, por encima de atribuciones de vínculos adscritos a una especificidad espiritual ${ }^{154}$. Estas atribuciones se constituyen en principios jurídicos, en virtud de los cuales se ejecutan ${ }^{155}$, pues de otro modo seria inviable la absolución de condenas espirituales por una autoridad secular incompetente ${ }^{156}$; desestimando con ello lo que el Concilio de Trento había establecido en materia de excomunión, al deslegitimar su revocación por el juez civil ${ }^{157}$. La Bula de Cruzada se sumaba a estos instrumentos ${ }^{158}$, haciendo de la contravención

153 Del papel desempeñado por el Consejo de Castilla como contraventor de las letras apostólicas se quejaron con frecuencia los nuncios, como ejemplo se puede ver la carta, de 6 de octubre de 1597, del Patriarca de Alejandria al Cardenal Aldobrandino, por la que el primero informa de la denegación de la ejecución de un Motu Propio de Clemente VIII por el Consejo, ASV, Fondo Borghese, III, 81 a, fol. 461r. La impotencia de la Nunciatura de intervenir y atajar la contravención llevada a cabo por el Consejo, llevó a que en este mismo año, en carta de 29 de septiembre, el nuncio escribiera a Felipe II quejándose de la retención de los despachos de Roma y consiguiente suspensión de su ejecución, Ibid. fols. $475 \mathrm{r}-475 \mathrm{v}$

154 El papel desempeñado por el recurso de fuerza al contravenir las censuras emitidas por el autoridad eclesiástica, aparece reflejado en unas instrucciones al nuncio de España, citado, 31 de julio de 1581, ASV, Fondo Borghese, I, 94-95, fols. 4r-57r.

155 De principio completamente legal y juridico califica Monsr. Traiano Mario, en carta a Felipe 11 de 16 de diciembre de 1581, con motivo de un conflicto surgido con el Consejo de Castilla por unos expolios de Córdoba y Sevilla, la excomunión, y como tal principio es como debia frenar las pretensiones del Consejo de hacer fuerza, ASV, Misc. Arm. I-XV, Arm. I, vol. 87, fol. 338v. Como principios diferentes en derecho considera, por ejemplo, B. GALLEGO DE VERA el entredicho y la cesación, op. cit.

156 Cfr. Prodi, P., /l sovrano pontifice, op. cit., pp. 242- 248.

157 Como no dejó de ser denunciado. En un discurso escrito contra este recurso, se hace hincapié en ello, el autor lo considera un "abuso" advirtiendo que "ll sacro Concilio di Trento nel cap. 3 della sett. 25 espresamente prohibise à tutti i Magistrati secolari, che non possano commandar agli ecclesiastici, che assolvano, o escomunichino, perche tal cognitione non tocca ad essi», "Abusi, danni, et inconvenienti, che si segueno dal ricorso per via di forza secondo hora si costuma", ASV, Fondo Borghese, 1, 775, fols. 225r-232v.

158 En este sentido, Juan de Paris, llamó la atención sobre el papel desempeñado por las indulgencias en caso de necesidad para evitar que el Pontífice pudiese obligar al súbdito a contribuir, op. cit., pp. 104-105. D. Ramos sobre este punto afirma: "Y que susuesto, que la Bula concede facultad para poder absolver, al que la tomó de Censuras, y penas: se podia absolver dichas irregularidades por la Bula. Y se confirma de las palabra de Summario... donde dize, que absuelve el Confessor de las Censuras de excomunion mayor, ó menor suspension, ó Entredichos y de todas las otras censuras. Luego da a entender, que hay otras censuras, a mas de las que ay dexa referidas, y explicadas y si ay otras Censuras. Las irregularidades de que hablamos lo serán. Y asi podrán absolver por la Bula. Y que sean penas Eclesiasticas, parece claron, a ello añade, 
de la autoridad espiritual un acto ejecutable ${ }^{159}$. La contravención de las armas espirituales como acto meramente jurídico impide la constitución de lo espiritual como una ratio sagrada y suprema. Con ello no se trata de que la autoridad temporal pase a subordinar la espiritual, pues lo que ocurre es que con la contravención se concede a las disposiciones pontificias el mismo significado que poseen las disposiciones reales, cuya ejecución también podía suspenderse como un acto de servicio al rey ${ }^{160}$.

La posibilidad de contravenir, merced a la excomunión, del entredicho, de la cesación a divinis, por medio de la bula In coena Domini, de la immunitas ${ }^{161}$, de la Bula de Cruzada - siempre conforme a derecho y no como acto meramente espiritual ${ }^{162}$, o con el recurso de fuerza, asegura la equiparación de la autoridad, al exigir el requisito de la aprobación previo a la ejecución; de aquí surge una división de la auctoritas que por sí impide la iniunctio de la potestas, que ésta se constituya en temporal o en

«El Confessor elegido por la Bula, puede absolver al que elige de la Excomunion, Suspension, y Entredicho... Porque la Excomunion, Suspension, y Entredicho, son censuras. Como consta claramente del Cap. Quarenti del verb. fignific. Y de la Bula claramente concede facultad de absolver de todas las censuras", Tratado sobre la Bula de la Santa Cruzada con unas advertencias tocantes a los ordinarios. Zaragoza, 1673, pp. 91-92.

159 Ello llevó al cardenal Aldobrandino a escribir al Comisario de la Cruzada, instándole a que se evitasen estos excesos, en carta de 29 de septiembre de 1596, ASV, Fondo Borghese, III, 35, fol. 16r. También, carta del cardenal Aldobrandino al cardenal de Sevilla, Roma 29 de diciembre de 1596, Ibid., fol. 16r-16v. Por otro lado, la desmesurada imposición de excomuniones latae sententiae, por causas vanales, en 10 que ello tenia de inserción en una rutina judicial, llevó al Nuncio Rossano a escribir al gobernador de Toledo instándole a que se excusen " ....si no fuere en cosas muy graves...", Carta de 20 de septiembre de 1567, ASV, Misc. Arm. i-XV, Arm I, 108, fol. $36 \mathrm{v}-37 \mathrm{r}$.

160 En la Corona de Castilla la voluntad del rey sólo obligaba cuando había sido consentida por el súbdito como un acto de servicio al rey y una vez se había constituido en voz soberana. Por tanto era un acto que afectaba a las relaciones entre el rey y el reino, y no tenia nada que ver con un supuesto "absolutismo" del monarca. Sobre este problema, M. Philippson, recoge la costumbre que se había establecido de no considerar las disposiciones obligatorias hasta que habian sido aprobadas por ei Consejo Real, si bien esta caracteristica era propia de la constitución castellana, aunque la aprobación llegaba desde diferentes instancias, según la naturaleza de la orden o mandato, y no necesariamente desde el Consejo de Castilla, op. cit., p. 135-136. El tema lo tratamos en "Uoluntas et iurisdictio: obediencia, ejecución, cumplimiento dela voluntad real en la Corona de Castilla en el siglo XVII", op. cit.

161 "...che questa obedientia e rispetto alli mandati Apostolici, et di questo se hanno prestato e precisano sempre essi (la Casa de Austria), et li suoi Ministri, et tribunali di Giustitia et tutti li Regni, che stanno sotto del suo governo, e Corona, et in quel che tocca all'impedir, et detener l'esecution delli Brevi, et mandati di S. St. ${ }^{a}$ non li passo gia mai per il pensamento di salir un purto, ne deviar dalla debita obedientia, et devotione alla Sede Aplica., ma si bene d'ovviar alli aggravi, che por false relationi, o per inavvertenza delli ministri aplici. si potebano fare, se non se ci mirasse bene avanti della essecutione, et in ciò non si ha da dubitare, che l'intento non sia sano, et che procede dal zelo di giustitia...", LÓPEZ DE MONTOYA, P., op. cit.

162 RodRiguez Lusitano, M., op. cit. Con respecto a las indulgencias por causa de excomunicón, p. 221; la cesación a divinis, p. 315; el entredicho, pp. 306 ss. 
espiritual, y que en cualquiera de los dos casos fuese absoluta. De ello se desprende que la autoridad espiritual podía no obedecerse si su orden era contra derecho ${ }^{163}$. Puesto que las excomuniones podian obviarse con el mero hecho de su presunta injusticia ${ }^{164}$, las armas espirituales se integraban en un entramado jurídico que anulaba la polarización de las relaciones entre lo temporal y lo espiritual ${ }^{165}$. También las decisiones pontificias debían ajustarse a razón y derecho ${ }^{166}$, en consonancia con el espíritu del recurso de fuerza ${ }^{167}$. De esta forma, la iurisdictio eclesiástica pasa a ser una iurisdictio más, mientras que la auctoritas del clero - representada de forma también dividida por los prelados, cabildos, dignidades, tribunales de justicia, Congregación del Clero-, se equiparaba con la de cuerpos, ministros, ciudades.

Al integrarse la dualidad conceptual en una relación entre sujetos jurídicos, el monarca ejerce su función de patrón y protector de los privilegios del estado eclesiástico, como "príncipe cristiano", como reconociera el Concilio de Trento, en virtud de su vínculo jurídico con el clero, en una relación de servicio como atributo del súbdito, lo que impedía todo «dominio absoluto" y la injerencia del poder temporal. Ni como patrón del clero ni como defensor de sus súbditos naturales, en este caso con el recurso de fuerza, el rey ejercía el señorío sobre la Iglesia, pues, como se insiste en la doctrina, estaba incapacitado para ejercer la jurisdicción espiritual en orden al bien temporal, o al fin espiritual ${ }^{168}$; extremo que es efectivo

163 Manuel Rodríguez argumenta, en cualquier caso, la desobediencia a la autoridad espiritual si su orden es contraderecho: “...si el subdito duda si esta obligado a obedecer, o le parece que manda (el prelado) contra derecho movido de causas leves no tiene obligacion de obedecerle, quando de su obediencia se teme mayor peligro...", op. cit., p. 48.

164 Principio que fue llevado a la práctica por Felipe II, por ejemplo, durante el pontificado de Pablo IV, cuando escribió a prelados, grandes, ciudades, universidades y cabezas de las órdenes de los reinos, que no guardasen las censuras o entredichos, porque los consideraba como nulos, injustos y, por tanto, sin fundamento, es decir, sin ejecución, CÁNOVAS DEL CASTILLO, A., “Roma y España a mediados del siglo XV|», Revista de España, T. II (1868), p. 38.

165 [Contin, T.A.], op. cit., p. 10.

166 De este modo se lo recuerda Felipe II a Sixto V, “Instruttione di quanto voi il comendator maggiore di Castiglia del nostro Consiglio di stato, et nostro Ambassator in Roma havete da fare in quella Corte», op. cit. WATT, J.A., op. cit. El Patriarca de Alejandría informa en carta de 6 de diciembre de 1597, que el presidente del Consejo “...ordina, che si faccino l'essecutioni senza tener conto delle censure presupponendo che siano ingiuste, ò nulle...", ASV, Fondo Borgese, 81 a, op. cit.

167 A los argumentos de su condición jurídica, y consonancia con la costumbre castellana, se añade su autorización legal: «....non ci mancano però scrittori dottissimi, che l'approvano per molte ragioni...", "Instruttione d'alcune cose di Spagna in materia di giurisdizione per il Nuntio di Spagna", 1591, op. cit.

168 Sobre este punto, José de CovarRubias advierte: "Toda esta doctrina legal procede sobre el principio de que en semejantes recursos la jurisdicción Real nada define sobre lo espiritual, sino sobre lo temporal», op. cit., pp. 156-157. Cfr. PHILIPfSon, M., op. cit., p. 106. 
merced a la immunitas. Pero también con el recurso de fuerza: con el legítimo conocimiento de las fuerzas como derecho tuitivo no se usurpa la jurisdicción eclesiástica ${ }^{169}$, puesto que no se trataba de un procedimiento jurisdiccional. El hecho de que exista el recurso de fuerza denota esta incompetencia. Los casos de violencia que no siguen "opinión probable», sino "razón aparente" o "sofística", eran contra derecho y jurídicamente inviables en la aplicación de la ley ${ }^{170}$. Contra derecho era la usurpación ${ }^{171}$, y los abusos que por este lado pudieran producirse. En este punto la bula In coena Domini encontraba su «ajuste» y su cumplimiento como expresión de una justicia legal común. Del mismo modo que con la immunitas, por este lado un rey sacerdos era jurídicamente inviable. No se trata sólo de que el monarca no instrumentalizaba su papel de patrón y protector del clero para "llevar las fuerzas", puesto que éstas correspondían jurídicamente al concepto de "rey natural», sino de que la necesidad de la ley de fuerza era la constatación legal de que el papel de patrón era una obligación del "príncipe cristiano" que no llevaba consigo ningún derecho o atributo en el orden espiritual ${ }^{172}$.

Con respecto a la retención de las bulas y de las letras apostólicas con el recurso de fuerza y el placet regio ${ }^{173}$, se hace inviable la ejecución de la voluntad del pontífice, en la que ni se procedía por vía de jurisdicción ${ }^{174}$, ni con la intervención de un rey patrón y protector del clero, sino tomando

169 "Epítome del articulo propuesto con la primera cuestión sobre los derechos y razones que tiene su majd....", op. cit., pp. 271r y 288v. A. Borromeo, "Isttruzioni generali e corrispondenza ordinaria dei nunzi: obiettivi e resultati concreti della politica...", op. cit.

170 Vid. Calasso F., "Causa legis. Motivi logici e storici del diritto comune», Rivista de Storia del Diritto, XXIX (1956), pp. 34-35.

171 «Epítome del artículo propuesto con la primera cuestión sobre los derechos y razones que tiene su majd...", op. cit., pp. 284r-285r.

172 Cfr. PhILIPpSON, M., op. cit. También, Nubola, C., "Visite pastorali fra Chiesa e Stato nei secoli XVI e XVII», II Concilio di Trento e il moderno, op. cit., pp. 383-413.

173 Por una pragmática de 20 de noviembre de 1569 se estableció el placet en Castilla (N.R. Lib. I tit. X, ley 12; lib. II, tit. IV, leyes 59 y 62 ), como recoge $M$. Philippson en su trabajo citado, no obstante que esta costumbre estaba con anterioridad arraigada en Castilla nos da noticia Monsr. Castagna en una carta a! cardenal Alessandrino, de 25 de septiembre de 1566, ASV, SS. Nunziature Diverse, 108 , fols. $63 r-65 r$.

174 «...su magd. ni sus consejeros no conocen por via de jursdiçion ni la tienen principal ni acesoriamente directe ni indirecte porque su conocimiento es por via extraordinaria cogniçion officio Regali por razon de defensa natural”, "Epítome del artículo propuesto con la primera cuestión sobre los derechos y razones que tiene su Majestad para conocer en las causas eclesiásticas por vía de fuerza", op. cit., fol. 293r. En el mismo sentido, Juan Luis López, afirma que «...en los Recursos protectivos no se exerce jurisdiccion propiamente, porque se procede de plano á remediar la violencia, é impedir, que el Juez Eclesiastico abuse y oprima". También el Conde de la Cañada: «El exercicio de esta potestad nativa no fue judicial, ni correspondió al imperio o jurisdicción, porque lo resistia la igualdad de los mismos hombres", op. cit., p. 149. 
como base el procedimiento ad melius informandum, propio del «rey natural». Prevalece una relación que obliga al príncipe soberano y a sus súbditos naturales con respecto a una fidelidad recíproca ${ }^{175}$, que también excluye la vía ejecutiva a los breves y disposiciones pontificias. No se trata de que, con el recurso de fuerza, el poder temporal pase a ejercer un dominio sobre el espiritual, puesto que no se circunscribe ni a una relación dual, ni a una facultad sobre el poder espiritual. De lo que se trata es de instituir la lealtad como un acto de obligación. Ello era posible con la exención de lo espiritual. Además, la contravención de la autoridad espiritual no denota la emergencia de una potestas absoluta por parte de Felipe II, sino todo lo contrario, la contravención asegura la división de la potestas. Se impone la ejecución jurisdiccinal, como acto separado de la ley ${ }^{176}$.

La voluntas emanada de una relación de lealtad se desenvolvía en el terreno de lo "accidental y dudoso", no reglado por el derecho que permitía un «ajuste» de voluntades y de "pareceres" 177 . El recurso de fuerza actúa en el campo de lo «indeterminado" como signo del vínculo de fidelidad entre rey y súbdito. Por lo que, estrictamente, no se trataba de un conflicto jurisdiccional el surgido entre la Santa Sede y la monarquía de Felipe II, en el ámbito de la Corona de Castilla ${ }^{178}$, como con frecuencia ha

175 «...por la fidelidad que los reyes deben a sus reinos, y reverencia al nombre de Dios, a lo cual juraron de amparar y defender las tierras que están debajo de su Majestad, doy gobierno de cualquier persona, que pretendiere hacerles fuerza, y agravio, que si a un hombre le hiciesen tutor de pupilos por leyes y fidelidad de tutoria, era obligado a volver por ellos, y no permitir que fuesen despojados de sus bienes, aunque fuese su padre natural, el que quisiese hacer este despojo sin razón, y puedes vra. Majestad es más, que tutor de sus reinos imprudente, y loca teología seria la que pusise escrúpulo en esta defensa...", [memorial anónimo], 1555, op. cit. fol. 13v. Sobre el vínculo que existe entre el recurso de fuerza y el rey natural, el cardenal Aldobrandino escribe al nuncio: “...intorno a levar l'abuso della forza, quel che dicono i Ministri Regii in sua difesa, che è cosa antica et naturale di quei Regni, è di poca sostanza, et si può facilmnte ribattere non essendo verisimite che i vescovi, i quali vengono nominati da S. Mtà. et dipendono da lui, vogliono abusar la loro autorità, oltra che questo rimedio della forza si usa più contra le provisioni Apliche., che contro altri, et realmente è stato introdotto per questo, come se ne vede l'effetto", 20 de diciembre de 1594, ASV, Fondo Borghese, II, 472, fols. 423v-424r.

176 Citando a Carlos Molina sobre lo que se lleva a cabo en Francia, Diego de CovarRuBIAS, defiende: «Ni si quiera el legado del Papa, ya sea a latere, ya sea enviado, puede ejecutar algo en el reino por autoridad del Papa, si antes no obtiene permiso expreso del rey, homologado por el Supremo tribunal real al cual pertenece la jurisdicción de lo que el legado pretende ejecutar", “De los asuntos y negocios eclesiásticos...", op. cit., p. 361.

177 Sobre este concepto: "Como en la misma republica temporal avria gran distancia entre ponerse a dudar uno sobre lo sustancial, en que ay leyes claras, y establecidas, o solo en lo accidental, y dudoso, sobre lo qual no ay nada determinado", [Obediencia a la Sede Apóstolica], s.a., B.N. V.E. $197 / 41$, fol. $9 v$.

178 Una consideración que la encontramos ya reflejada desde las primeras crónicas. Así, Antonio de LOREA, refiriéndose a las diferencias surgidas entre Felipe 11 y el papado, parte de esta lectura: "Las jurisdicciones de el Santo Pontifice, y del Rey Catolico, como se fundaban en 
venido siendo considerado; y ello no obstante que normalmente la tratadística llamase la atención sobre la naturaleza no judicial del recurso de fuerza ${ }^{179}$. No se trataba de una disputa entre jurisdicción real y jurisdicción eclesiástica. Con el recurso de amparo, el monarca ejercía su función de príncipe soberano, como "rey defensor» de agravios y de fuerzas, no de juez competente ${ }^{180}$, según un concepto de soberanía natural ${ }^{181}$, como establecía la constitución castellana ${ }^{182}$. Lo que el nuncio califica como "Sentencia autoritaria», al serlo, como él mismo apunta, por «via d'aggràvio" o de "querelle" 183 , aunque los nuncios lo señalen con el apelativo de

el servicio de Dios, aumento de la Fe Catolica, y castigo de los Ereges, no daban lugar à que las turbassen leves motivos, y teniendo tan profundas raices en el amor de ambos corazones, ni estas causas, ni mas graves pudieron poner discordia entre un Pontifice tan santo y un Rey tan ajustado", El bienaventurado Pio V pontifice máximo de la lglesia religioso de la sagrada orden de predicadores crónica de su santa vida, prodigiosos hechos, y gobierno universal eclesiástico de todo el orbe. Madrid, 1673, p. 181.

179 CovarRubias, D. DE, De los asuntos y negocios eciesiásticos..., op. cit., p. 353. SALGado de SOMOZA, F., Tractatus de supplicatione ad Sanctissimum a litteris et bullis apostolicus, necquam et importune impetratis in perniciem reipublicae, regni aut regis, aut juris praejudicium, et earum retentione interim in Senatur. Madrid, 1639. El Conde de la Cañada, vincula el recurso con la defensa natural y con la soberanía, "...en defensa del Estado", Observaciones prácticas sobre los recursos de fuerza: modo y forma de introducirlos, continuarlos y determinarlos en los tribunales superiores. Madrid, 1793, p. 314. Como excepción a estas acepciones, en el siglo xvill, está el caso de José Covarrubias, y ello no obstante que reconozca el carácter extrajudicial del recurso y su naturaleza de auxilio y protección dispensado por el príncipe soberano, principios en los que se basaba su no judicialidad, Máximas sobre recursos de fuerza y protección, con el método de introducirios en los tribunales, op. cit.

Jesús Maldonado distingue entre, los recursos de fuerza en asuntos judiciales regulados en 1855 y los anteriores a esa fecha, "recursos de protección» que no terían origen en el ámbito judicial, aunque él identifica estos últimos no con la soberanía y el derecho natural, sino con la potestad de administración y de gobierno. Christian Hermann ha destacado esta naturaleza extra-judicial del recurso, no obstante, lo considera como una facultad de la jurisdicción real, op. cit., p. 29. Vid. también, Serrano, L., op. cit., p. 93-94. Cfr. Bruno, C., op. cit, pp. 230-231.

180 En el tratado sobre el recurso de fuerza del siglo XVIt citado se constata este hecho, pues, a través de este recurso, «...no hazen los consejeros de su magd. como juezes para quitar las fuerzas por autoridad judicial porque directe neque indirecte principal ni acesoriamente no tienen jurisdición solo se haze per modum extraordinarie cognitionis officio Regali in vim defentionis naturalis", "Epítome del artículo propuesto con la primera cuestión sobre los derechos y razones que tiene su Majestad para conocer en las causas eclesiásticas por vía de fuerza", op. cit. fol. 279 r. Sobre esta circunstancia Vicente de la Fuente en su vehemente obra contra el recurso de fuerza y retención de bulas, rechaza este principio defendido por la doctrina y por los propios protagonistas del conflicto: “¿Podrá negarse que por el derecho de retención se arroga el príncipe el derecho de conocer en cosas eclesiásticas?", op. cit., p. 93.

181 SKINNER, Q., op. cit., p. 244.

182 Sobre este purito, Francisco de Ocampo sostiene que el monarca era el último garante de la Orden de Santiago, al poder recurrir sus miembros «en caso que tenga justa causa... según el árbitro de buen varón», y ello, no en calidad de juez competente, sino "...como a rey y príncipe soberano, para que le socorra en aquel gravamen y fuerza injusta que se le hace...", Obligaciones de los caballeros de la religión de Santiago, pp. 117v-118r.

183 Memorial enviado por el Patriarca de Alejandría al cardenal Aldobrandino, 5 de noviembre de 1594, ASV, Fondo Borghese, I, 772, fol. 903. 
«rimedio straordinario», se refiere a la naturaleza no judicial del recurso de fuerza, pues no se trata ni de un juicio extraordinario ni de un medio ejecutivo ${ }^{184}$. Su significado, declaratorio del derecho de defensa del súbdito ${ }^{185}$, no lo era ni de la iurisdictio ni de la potestas ${ }^{186}$, sino de una relación medida en términos de lealtad ${ }^{187}$. Esto quiere decir que la naturaleza del recurso de fuerza era básicamente contractual. Al situar sus decisiones en el ámbito de lo no determinado por el derecho, llama a la voluntas como signo de la connivencia y relaciones de fidelidad - que denota un pacto de servicio- entre un rey defensor" de agravios y sus servidores, como recurso de amparo frente a la sentencia inicua.

En materia de retención de bulas el recurso de fuerza permitía al clero sancionar la contravención de la autoridad espiritual, bajo supuestos de obrepción o subrepción ${ }^{188}$, con arreglo a la fórmula del derecho castellano obedézcase pero no se cumpla ${ }^{189}$. Pero, de lo que se trataba era de inte-

${ }_{184}$ Tal como lo encontramos, por ejemplo, definido en el siglo XVIII al identificarlo, como medio extraordinario, con la "potestad económica". Así, aunque se reconoce que "El Derecho Natural, que permite usar de la fuerça para resistir otra, obra con mas eficacia en los Principes, como cabeza para indultar à sus Miembros, de los peligros y daños", a continuación se especifica: "Ultimamente, las Venerables Leyes del Reyno señalan, aquellas Reales prerrogativas con que sus Soberanos, en virtud de una Potestad economica, y preservativa, corrigen y enmiendan los delitos de los Eclefiasticos; alçan las fuerças; mantienen en su vigor las dispoficiones del Concilio de Trento; Examinan y retienen las Bulas Apostolicas; y oponen su Real autoridad à la inobservancia, ò derogacion de los derechos, y privilegio de sus Vassallos", Discurso político cristiano de un castellano viejo en defensa de su patria y de las regalias del rey..., op. cit., pp. 14-15. En el mismo sentido se profuncia Manuel Antonio de Castro, Prontuario de práctica forense. Buenos Aires, 1945, según cita de LAVAGGI, A., op. cit., p. 90.

185 El prof. José Manuel Pérez Prendes, ha destacado en este sentido que el recurso de fuerza constituía una garantía de los derechos del súbdito frente a abusos jurisdiccionales, "Relaciones Iglesia-Estado en la formación del Estado Moderno. El Real Patronato; aportación para un estado de la cuestión". Etat et Eglise dans la genese de L'Etat Moderne, op. cit., p. 250.

${ }_{186}$ ALONSO, S., op. cit., pp. 97-113.

${ }_{187} \gamma$ ello por cuanto, en concreto, en materia de retención de bulas, como recoge Diego de Covarrubias, “...una cosa es mandar el poder secular en absoluto, que nadie obedezca las letras apostólicas que aplican la justicia o conceden alguna gracias, y otra, muy distinta, disponer que sin su beneplácito y examen nadie las obedezca ni las ejecute", "De los asuntos y negocios eclesiásticos...», op. cit., pp. 362-363. Cfr. Fuente, V. de la, op. cit., p. 135.

188 Sobre este punto DIEGO DE COVARRUBIAS aclara que: "Para que nadie piense que los tribunales reales de España se hace alguna cosa en el más mínimo detrimento de la autoridad del Romano Pontífice por lo que se refiere a los negocios eclesiásticos... ha de tenerse muy en cuenta que alguna vez se difiere la ejecución de las tetras apostólicas y se deja en suspenso por decreto o disposición del Consejo real, para que, mientras tanto, el Vicario de Cristo se cerciore de cuántos y cuán grandes inconvenientes trae aparejados a esta nación la ejecución de muchas concesiones que el Sumo Pontífice hace... asi interim no se informe mejor el Papa de lo que es conveniente para la pública utilidad designio que a cada paso se expresa en las constituciones imperiales y pontificias...", De los asuntos y negocios eclesiásticos que suelen ser examinados en los tribunales del reino de Castilla, op. cit., pp. 366-367.

189 Ello lo encontramos reflejado ya en Francisco SALGADO DE SOMOZA, op. cit. Vicente DE LA FUENTE también se hace eco de esta característica, op. cit., pp. 134-135. 
grar las disposiciones pontificias y la autoridad espiritual en el entramado legal de la monarquía según el cual para que una orden pudiera cumplirse debía primero ser autorizada por las potestates a quienes, de hecho, competía su ejecución ${ }^{190}$. Las bulas y breves papales, no podían ejecutarse «sine autoritate et consensu principis» ${ }^{191}$, pero tampoco sin la sanción del súbdito; lo que implicaba en ambos casos su inserción en una relación de servicio al rey. La consecuencia es que con el recurso de fuerza se impedía que las letras apostólicas fuesen ejecutadas por una cuestión no sólo de potestas sino específicamente de potestas espiritual. Teniendo en cuenta la emergencia del sentido de lo sagrado a partir del Concilio de Trento ${ }^{192}$, de esta forma se evitaba que se produjese una sacralización de la plenitudo potestatis papal, pero también de la potestas iurisdictionis, que, no obstante su indeterminación, se mantenía diferenciada de la potestas ordinis ${ }^{193}$, y que con ambas la superioritas iure divino del papa se materializase mediante un tipo de precepto constituido jurídicamente en superiori tas integrado en una «jurisdicción sacra» ${ }^{194}$. Por lo que si un juez eclesiástico denegaba la apelación legítima, con el recurso de fuerza se evitaba la constitución de una potestas espiritual suprema al margen de la institución real y con ello la formación de una «ejecución espiritual»» o sacra ${ }^{195}$, pues el rey no podría intervenir como jurisdic-

190 Así lo expresa Diego de Covarrubias citando a Juan Driedo: «una cosa es mandar el poder secular en absoluto, que nadie obedezca las letras apostólicas que aplican la justicia o conceden alguna gracia, y otra, muy distinta, disponer que sin su beneplácito y examen nadie las obedezca ni las ejecute», De los asuntos y negocios eclesiásticos..., op. cit., pp. 363-364,

191 «Instruttione di quanto voi il Comendator maggiore di Castiglia del nostro Consiglio di stato, et nostro Ambassator in Roma havete da fare in quella Corte", op. cit.

192 VISMARA, P., op. cit., p. 204. TURCHINI, A., "La nascita del saderdozio come professione", Disciplima dellanima, disciplina del corpo e disciplina della società moderna. Bologna. 1994, pp. 225-256.

193 Manuel Ambrosio de Filguera distingue ambas potestades como sigue: “Es vulgar división de la potestad que comunmente enseñan aquí los doctores, porque distingue potestad de jurisdicción, y potestad de orden: esta es la que inmediatamente comunica Christo en el acto del orden, y se llama remota, porque por ella se hace uno capaz de jurisdicción de ligar, y absolver; aquella es la que después da la Iglesia, y se llama próxima", Suma de casos de conciencia que se disputan en la teologia moral. T.I. En que se trata todo lo perteneciente a los sacramentales, también de las inóulgencias, y la Bula de Cruzada. Madrid, 1684, p. 188. Vid. AlBerigo, G., Lo sviluppo della dottrina sui poteri nella chiesa universale. Momenti essenziali tra il xvi e il xix secolc. Roma, 1964; "La potestà episcopali nei dibattiti tridentini». "I Concilio di Trento e la Riforma tridentina, Ruma, 1965, p. 511.

${ }_{194}$ Sixto $V$ en carta de Felipe II, de 7 de agosto de 1587 , alude a este concepto de una superioritas sacra, con motivo de la pragmática de los títulos de octubre del año anterior: "César Octavio y otros Emperadores paganos mostraron respeto á la sacra jurisdicción, que, para dictar leyes á los sacerdotes y demás personas sagradas, hacianse elegir pontífices". Hinojosa NaveROS, E., op. cit., p. 324 .

195 «...tutti gli ordinari pretenderiano esser Papi nelle lor diocesi con fare molti aggravii, et non ammettere appellationi, et fare altre essorbitanze, alle quali rimedia il benefitio dell'ausilio suddetio della forza...". Madrid, 31 de julio de 1581, op. cit. fol. $9 v$. 
ción suprema por tratarse de causas eclesiásticas: «...en las cosas espirituales, ninguna cosa puede hazer el secular, sino es concediendoselo el derecho" " ${ }^{196}$. Con la mediación del derecho es posible la contravención, no la intervención. La contravención activaba la lealtad.

El clero se sirve de la ley de fuerza ${ }^{197}$, como recurso de amparo frente al presunto agravio del juez eclesiástico, en su condición temporal como súbditos -y ello no obstante los intentos de la Nunciatura de Madrid de persuadir a arzobispos, obispos y a la Congregación del Clero de no acudir al «rimedio straordinario» del juez secular, o con la condena expresa de este tipo de recursos-, sancionando el principio de lealtad al rey. Consecuentemente, la unitas espiritual y dogmática no es constitutiva de una relación específica entre el clero y el pontífice ${ }^{198}$. El vínculo de la religión sólo es integrante en términos jurídicos de libertad y de privilegio, lo que significa que la moral y el dogma no obligan por sí. La obediencia se expresa con respecto a la norma jurídica; sólo su «ajuste» legal vincula ${ }^{199}$. De esta forma, el vínculo de la unidad y de la concordia al que apela el papado, en su relación con la monarquía, no se funda, estrictamente, en la religión, sino, con la intervención de lo común legal, en una «obligación en justicia" ${ }^{200}$. La fidelidad entre el súbdito religioso y el "señor natural" encontraba en estas causas su aplicación legal ${ }^{201}$. Además, y en contra de lo estipulado en el Concilio de Trento, se admitía el recurso en la sentencia interlocutoria, lo que desplazaba, no sólo a la jurisdicción ordinaria de

196 Rodriguez Lusitano, M., op. cit., p. 222.

197 El recurso de fuerza era normamente aceptado por el clero. Sin embargo, los abusos, o su instrumentalización, podían ser motivo de rechado, no el recurso en sí. SANCHEz BELLA, l., recoge una carta del arzobispo de Lima a Felipe 11 de 27 de abril de 1584, en la que tiene el recurso «por bueno", mientras llama la atención sobre el "exceso" en las leyes, Iglesia y Estado en la América española. Pamplona, 1991, p. 28, n. 46.

${ }_{198}$ Por tanto, era algo más que la fe y el dogma lo que vinculaba a la monarquía hispánica con el Papado. Cfr. PhILIPPSON, M., op. cit. Jedin, H., "Ciò che la storia del Concilio si attende dalla storia ecclesiastica italiana", // Concilio di Trento, Rivista Commemorativa del IV Centenario, año II, n. 2, abril, 1943, p. 174; Storia del Concilio di Trento. 5 vols. Brescia, 1973-81. G. Alberigo, "Du Concile de Trente au tridentinisme", Irénikon, 54 (1981), p. 206.

199 Cfr. DiNı, V. "Prudenza, giustizia e obbedienza nella costituzione della ragione di stato in Spagna e in Francia. Assaggi di lettrura e prospettive di reicerca", Aristotelismo politico e ragion di stato. Atti del Convegno Internazionale di Torino (11-13 febrero 1993). Firenze, 1995, p. 263.

200 Turrini, M., La coscienza e le leggi. Morale e diritto nei testi per la confessione della prima età moderna. Bologna, 1991.

201 Extremo que fue contradicho por la Nunciatura: «...per concessioni Apliche. et Juspatronato Regio provedendo tante intrate ecclesiastiche et dignità in Spagna come provede non le manca modo di contener a sua divotione il clero per altro camino et che non venirà Papa et Ministri suoi che non habbino principal mira di conservar la fidelità et il rispetto al nome Reale nell'ordine ecclesiastico...", [Memorial del nuncio, Patriarca de Alejandría, para Roma, Cardenale Aldobrandino enviado con carta de 6 de diciembre de 1597], 
los obispos o a la jurisdicción delegada del vicario general, sino al tribunal de la Nunciatura a favor de las audiencias reales o del Consejo de Castilla ${ }^{202}$, como supremo representante de una relación de servicio y fidelidad al rey.

La división de la autoridad, que competía al "reino natural» ${ }^{203}$, se integraba en una relación de lealtad reciproca entre rey y súbdito religioso. De esta forma, la auctoritas se vinculaba necesariamente con la autoridad real, permitiendo la transacción de necesidades y de obligaciones. Como expresión de esta lealtad, aunque se introdujeron los controles precisos para evitar la subversión de lo temporal, también se disponen el derecho de patronazgo - cuyos conflictos Felipe II entregó al Consejo por vía de fuerza ${ }^{204}$ - y la immunitas ${ }^{205}$. Pero, en ambos casos, su ejecución correspondía a la autoridad eclesiástica, por vía jurisdiccional, y que se integraban en el deber de auxilium et consilium a partir de los cuales se instituye aquella división de la auctoritas, referida a un servicio espiritual. Ello se cumplía con las "obligaciones" del estado eclesiástico en su conditio religiosa. Sin embargo, el recurso de fuerza por sí se constituía en la contrapartida regia de una relación de lealtad recíproca que, enmarcada en el deber de defensa y correspondiendo su ejecución a la autoridad secular, llevaba a la práctica legal la conditio temporal del clero como súbdito. De

202 Vid. Benlloch POVEdA, A., "VI. Jurisdicción eclesiástica en la Edad Moderna: el proceso" en, Instituciones de la España Moderna, op. cit., pp. 113-142.

203 Y ello no obstante que, como se denunció por la Nunciatura, el Consejo Real pudiera "abusar" del recurso no otorgando las apelaciones. De la división de la potestas también se hace eco el nuncio: “...et se bene li Ministri del Papa che sono stati in Spagna per pura necessità di obviare alle rotture et disordini maggiori hanno talvolta dissimulato et confessato ch'il rimedio della forza è necessario per freno de Prelati et Giudici ecclesiastici in queste Regni et non deve esser' l'antico uso di esso rimosso dalla Sede Apostolica non di meno quanto alle persone ch'hanno à cognoscere della forza et quanto al modo di usare detto rimedio sempre si è contradetto in Roma...", [Memorial del nuncio, Patriarca de Alejandría, para Roma, Cardenale Aldobrandino enviado con carta de 6 de diciembre de 1597], op. cit.

204 J. Maldonado, op. cit., pp. 299 y $301-302$. Sobre el derecho de patronato el nuncio defiende que por este lado, como contrapartida al recurso de fuerza, podría el rey obtener la necesaria fidelidad del clero: “...et io dico all'incontro a V.Mta. che per concessioni Apliche. et Juspatronato Regio provedendo tante intrate ecclesiastiche et dignità in Spagna come provede non le manca modo di contener a sua divotione il clero per altro camino et che non venirà Papa et Ministri suoi che non habbino principal mira di conservar la fidelità et il rispetto al nome Reale nell'ordine ecclesiastico...", [Memorial del Nuncio, Patriarca de Alejandria, para Roma, Cardenale. Aldobrandino enviado con carta de 6 de diciembre de 1597], op. cit. HERMANN, CH., L'Eglise d'Espagne... op. cit., p. 45.

205 En materia de litigios del clero por razón fisca!, se entregaron las causas a los tribunales reales, en menoscabo de los tribunales eclesiásticos, en 1598, Ch. HermanN, op. cit., p. 31. Con respecto al servicio de millones habrá que esperar hasta el 26 de agosto de 1636, Ley 15 del tit. $2 .^{\circ}$ del lib. II de la Novisima Recopilación, para que los conflictos se entreguen al Consejo Real por vía de fuerza. 
esta forma, el clero se encontraba también obligado con respecto a lo temporal, y al serlo por razón natural, con independencia de lo espiritual en una «jurisdicción universal». Por este lado, la exención del clero por causa temporal era jurídicamente inviable, lo que, de nuevo, evitaba el poder indirecto de la "república espiritual" sobre lo temporal ${ }^{206}$. Ello obliga, a la vez que explica, a que la immunitas se constituya como un principio de servicio al rey que, siéndolo por razón espiritual, se enmarca jurídica y legalmente - merced a una convergencia legal- en los principios constitutivos del servicio del súbdito secular en sus diferentes formas ${ }^{207}$. En este contexto, la reciprocidad de la relación entre rey y súbdito religioso, con el recurso de fuerza, confluía en el Consejo de Castilla como máximo representante de la persona real, pero también de los derechos del súbdito en función de una relación contractual. Gracias a esta fidelidad se obtenía la lealtad en materia temporal del clero a un rey temporal, exento de lo espiritual, a quien "...ut Regi nostro ac Dominio natural fideliter obedire» ${ }^{208}$. Se sellaba su vínculo de unión con sus súbditos naturales con la «independencia» que le concede la exención, adoptando dicho nexo una forma pactista, en consonancia con el servicio del súbdito secular. Ello no quiere decir que la immunitas se convierta en un privilegio «real» ${ }^{209}$, pues su articulación en una relación de servicio al rey se constituye sobre la base de su razón espiritual legitimada con los indultos papales. Pero, esta legitimación depende, a su vez, de una relación de servicio al rey, común a seglares y eclesiásticos. Por lo que, con la intervención del recurso de fuerza se impedía que la immunitas, como razón espiritual, se constituyese y fuese constitutiva de una comunicación dual, entre poder espiritual y poder temporal, en conformidad con los principios judiciales de la iurisdictio.

Si la sanción del clero castellano del recurso al «rey natural» podía encontrar su legitimación en el hecho de que la autoridad del príncipe, con arreglo al principio suareciano de soberanía in suo ordine ${ }^{210}$, no subordi-

206 “...la República espiritual es Juez de la çivil en las causas spirituales por la potestad di recta que tiene y en las temporales quando conviene ordenarlas al bien y fin espiritual y por esta causa los Pontifices eximieron al clero en quanto sus personas y bienes del foro de la potestad civil y real...", Epitome del artículo propuesto con la primera cuestión..., op. cit. fols. 278v-279r. Vid. DOWNS, J.E., op. cit.

207 CÁRCELES DE GEA, B., "Ragione giuridica, ragione politica dell'immunitas ecclesiastica nella Corona di Castiglia nel ' $600 "$, op. cit.

208 Como se expresa en "Congregatio ex universis Metropolitanis et cathedralibus Regnorum Castellae et legionis, Vallesoleti convocata et collecta sempiternam fidelitatem", ASV, Fondo Borghese, III, 63a, fol. 326r.

209 Tal como pudo defenderse por la doctrina, vid. DowNS, J.E., op. cit.

210 SÁnChez AgeSTA, L., "El concepto de soberania en Suárez", Archivo de derecho Público, n. ${ }^{\circ} 1$ (1948), pp. 51-71. 
naba la autoridad espiritual, ello era legalmente factible porque la iurisdictio quedaba separada e incompetente frente a una instancia suprema: la jurisdicción soberana era jurídicamente inviable ${ }^{211}$. El recurso de fuerza era la expresión legal de esta inviabilidad. Con la separación jurisdiccional a través de la ley de fuerza primaban valores como la lealtad, plenamente activa en el siglo xVI, como antesala de la iurisdictio: puesto que el rey no podía ejercer potestad de jurisdicción sobre el clero el dominio debía asentarse en un principio no jurisdiccional, que vinculara al estado eclesiástico y al estado secular en un instituto común, sin negar por ello el principio de jurisdicción eclesiástica, que Felipe II nunca cuestionó ${ }^{212}$. Esa es la función que desempeña el concepto de reino y «rey natural», definidos según la idea de defensa y de lealtad, no de potestas, pero tampoco de justicia, y este es el significado que adquiere el recurso de fuerza. Aunque Felipe II basase su auctoritas en el "...dominio et suprema regalia et giurisdittione temporale...» ${ }^{213}$, por «razón de dignidad», y que Diego de Covarrubias llamase "Mayoría» ${ }^{214}$, ello no podía confundirse con el concepto de "rey natu-

21 El concepto de jurisdicción soberana como lo encontramos expresado, por ejemplo, en Francisco Suárez, debe entenderse en la acepción de dominio y no de facultad judicial. Vid. SANCHEZ AGESTA, L., op. cit., p. 59. En el mismo sentido debe entenderse la legitimación del recurso de fuerza sobre la potestad de una jurisdicción extraordinaria suprema, como lo encontramos en el siglo XVII, en Pedro GONZÁLEZ DE SALCEDO, pues como procedimiento extrajudicial es ajeno a la iurisdictio, a la administración de justicia: "Sed in nostro casu, nec ius ullum quaesitum est parti, quia extraiudicialiter proceditur, et in vim supremae extraordinariae iurisdictionis", De lege politica eiusque naturali executione et obligatione tan inter laicos quam ecclesiastico. Madrid, 1642, p. 122.

212 Así lo dejó expresado Felipe II: «...el obispo de Ascali, que vino aquí por Nuncio de su Santidad, nos ha dicho de su parte que unos de los medios que ha pensado para conservar no solamente las provincias y estados que están limpios de herejia, pero aun los infestos y sospechosos de ellas, mantener en su ser y fuerza la jurisdicción eclesiástica, sin permitir que en manera alguna sea perjudicada, y usurpada... y que siendo nos príncipe tan católico y hijo obedientísimo de la Santa Sede Apostólica, deberiamos proveer en esto de remedio conveniente... nos ha parecido para asentar esto de una vez y estar con el ánimo quieto, y no incurrir con descuido en las censuras de la Bula in coena Domini, escribiros esta y encargaros tengáis particular cuidado en favorecer la jurisdicción eclesiástica y de no venir contra ella en cuanto no fuere contra preeminencia real...", [carta dirigida al duque de Alcalá de 24 de marzo de 1567], BAV Barb. Lat. 5382, fol. $56 r$. En las instrucciones derigidas a Felipe III también encontramos la misma idea, asi le aconseja que favorezca al papa, "...cuyas demandas atenderán al bien público y de la religión, o de la conservación de la jurisdicción eclesiástica», op. cit., p. 662. Vid. BORROMEO, A., op. cit.

213 "Instruttione di quanto voi il Comendator maggiore di Castiglia del nostro Consiglio di stato, et nostro Ambassator in Roma havete da fare in quelia Corte", 31 de julio de 1568, ASV, Misc. Arm. I-XV, Arm.II, vol. 102, fols. 366r-373 (bis).

214 "De la suprema jurisdicción del rey que llamamos mayoría, la cual, en nombre del rey ejercen las audiencias" en, Textos juridico-políticos. Madrid, 1957, pp. 297-339. Conceptuada dicha jurisdicción como tempora! y civil por Covarrubias, sostiene que la jurisdicción suprema reside en el rey, por lo que se puede apelar al rey de los obispos que ejercen jurisdicción temporal, p. 303. 
ral» al que no se procedía por apelación ${ }^{215}$, según una idea de rey justiciero, sino por amparo, con las funciones de un «rey defensor» de agravios y de los oprimidos. Diferencia que se materializaba con la distinción conceptual entre "causas eclesiásticas» y "causas temporales» ${ }^{216}$. Una diferenciación que lejos de contribuir a la separación del clero mediante la jurisdicción espiritual y la immunitas por razón temporal, la impide al ponerse al servicio, en ambos supuestos, de la doble condición del clero, de súbditos y religiosos, como principio legal. Gracias al recurso de fuerza la lealtad entre rey y súbdito se mantiene plenamente operativa elevando al rango de obligación los principios no judiciales y no determinados por el derecho.

Por consiguiente, una potestas iurisdictionis que no era ni civil ni religiosa sino jurídica y legal y que se irá progresivamente constituyendo como política ${ }^{217}$, prevalece como instrumento de una comunicación entre estados que garantiza una relación de lealtad, sujeta a voluntad, sin que por ello se crease un orden de sujeción apoyado en una potestas espiritual - sacra, a la que se le debe por razón y derecho divino "observancia" y "reverencia»; llegase ésta de manos del derecho pontificio, o de las sentencias del juez eclesiástico. Como consecuencia, el pastor universal no podía constituirse in spiritualibus como algo diferenciado jurídicamente de los principios del derecho castellano, pero tampoco la autoridad eclesiástica. Lo que significaba que el derecho divino como legitimador de principios jurídicos del clero será superado por aquellas reglas "sustanciales» adscritas a la plenitudo quaedam iuris, en la que vienen a insertarse principios como la plenitudo potestatis papal, la immunitas, el privilegium fori o la bula In coena Domini. El derecho divino no podía disponerse como un elemento diferencial, como derecho privativo de la Iglesia, de la iurisdictio espiritual $^{218}$. La potestas iurisdictiones eclesiástica se apoyará en el origen

215 En unas instrucciones al nuncio de España se encuentra la identificación entre jurisdicción real, como autoridad real, y recurso de fuerza, relacionada, a su vez, con el principio de defensa, ASV, Fondo Borghese, 1, 94-96, fol. 9v. No obstante, las imprecisiones han dado lugar a interpretaciones erróneas. Cfr. SANTAREN, N., "De los recursos de fuerza y de protección", Revista General de Legislación y Jurisprudencia, t. 35 (1869), pp. 190-196. También, la carta del arzobispo de Lima de abril de 1584, recogida por Bruno, C., op. cit., p. 225.

216 Vid. PÉrez Prendes, J.M., op. cit.

217 Francisco VARGAS, describe la potestas iurisdictionis como sigue: "Potestas iurisdictionis externae, quae ad politicam ecclesiae gubernationem spectat...", De episcoporum iurisdictione et Pontificis Max. autoritate. Roma, 1563, p. 54.

${ }_{218}$ Como se alentaba desde la Santa Sede: "Non confondano li due jiurisditione per lege divina distinte, et ordinate. Ne faccino cosa per la quale possa restare offesa stia in un minimo punto l'authorità, Podestà, et Prerrogativa ecclesiastica, et cosi facendo primo che il male passi più avanti questi Regni sarano più fermamente stabili et sicuri...", "La scrittura de che si fà mentione ne la precedente lettera (al cardenal Alessandrino), et che si mandò c. essa è la seguente», 2 de marzo de 1568. Se entregó la carta a Felipe II para que la leyese, ASV, Misc. Arm. I-XV, Arm. I, 
divino en los mismos términos que el poder temporal, como causa última del poder y como razón espiritual ${ }^{219}$; pero su función será jurídica y legal con idéntico significado que la jurisdicción temporal. Como garantía de esta función, el recurso de fuerza, con el procedimiento, que encontramos ya formulado durante el reinado de Felipe $\mid{ }^{220}$, por el que se determinaba si se había cometido alguna irregularidad jurídica por parte del juez eclesiástico, se garantizaba el "ajuste» legal de la jurisdicción eclesiástica conforme a derecho ${ }^{221}$. De esta forma se primaba el derecho castellano frente a otras fuentes juridicas como las provenientes de los sagrados cánones y del Concilio de Trento, pero en lo que éstas pudieran tener de afirmación del derecho divino, como separación jurídica, a medida que se estaba produciendo un distanciamiento entre lo sagrado y lo profano ${ }^{222}$. El

vol. 108, fols. 111v-115r. Como derecho humano, conforme con el divino, se considera en un memorial del reinado de Felipe III que utilizamos más arriba, la inmunidad eclesiástica, “Epítome del artículo propuesto en la primera cuestión sobre los derechos y razones que tiene su Majd. para conocer en las causas eclesiásticas por vía de fuerza", fol, $279 \mathrm{v}$.

219 “...omnes iurisdictionis potestatem non ab homini, sed a Deo immediate suscipere", $F$. Vargas, op. cit., p. 51. Vid. DOWNS, J.E., op. cit., pp. 5, 83-84

220 Cfr. AldEA, Q., op. cit

227 En un discurso que citamos más arriba, se alude a este procedimiento como "Quarto abuso nell'estendersi : Giudici secolari con la maniera di Decretare à più di quello, che ricerca il rimedio della forza", pero también en el séptimo abuso. En concreto advierte que: "Dilatasi in estremo questo rimedio da un modo di decretare inventato per quanto s'intende, da pochi anni in quà, che è, ch'il Giudice ecclesiastico facendo la tal cosa, come per essempio, dando la tal dilatione non fà forza, et non la dando la fà, et simili, che non è altra cosa, che prescrivere la forma à i Giudici ecci. come habbino da decretare, et giudicare, et usurparsi la giurisdizione ecclesiastica in comandar alli istessi Prelati quello, che habbino da fare il che senza dubbio hà bisogno di tal rimedio". Frente a este "abuso" propone una solución: "Dal che si scopre la causa, perche più forse in questi Regni, che in altri i Giudici ecclesiastici sono punti ad esseguir contra giustitia le loro sentenze, il che non sarebbe se tutte le volte, che eccedono i termini, aspettassero il dovuto castigo da i propii superiori, et levatane la causa, si levarebbe l'effetto, et si toglierebbe il dubbio, che mostrano alcuni d'haver, che senza il rimedio della forza non si potrebbero governare questi Regni", "Abusi, danni, et inconvenienti, che si segueno dal ricorso per via di forza secondo hora si costuma". Desde la Nunciatura también se reprobó este procedimiento: “...quando il giudice ecclesiastico fa alcuno errore circa il diritto, non tocca al secolar d'enmendarlo, ma ha il suo superior, che può corregerlo, al quale può haver ricorso il laico", Memorial enviado por el Patriarca de Alejandria al cardenal Aldobrandino 5 de noviembre de 1594 op. cit.

222 En palabras de Girolamo Hurtado encontramos expresado este problema: “.... signore Presidente depende l'appelatione, o vero reprobatione, di quelche con maturo essame, essatto studio, et per molto tempo si è giudicato, et poi in materia ecclesiastica, et appresso Giudici secolari, che possono molte volte non haver tanta pratica di materie benericiali, nè dello stile della sacra Curia, et decreti particolari della Sarta Sede, tutte cose differentissime della sua professione. Da che nasce che per non errare è forza si pigli uno de due partiti, ò vero fidarsi più delli Magistrati ecclesiastici, che con tanto studio cercano sodisfare al lor'obligo; o vero issaminare più di proposito ciascheduna causa, dandole più tempo per intender senza precipitatione li suoi meriti", "Ragionamento fatto dal dottore Girolamo Hurtado Penitenciario di Piacenza nel Conseglio Regio supremo di Castiglia, essendo tirata à quello per via di torza dal D. Vidal suo contrario, una sententia 
recurso de fuerza refrenda los sagrados cánones en tanto que se constituyeran en derecho legal de la urepública temporal», como instrumento del «bien público», el cual también contemplaba las necesidades de la respublica christiana. Se evitaba la sacralización. El «trato terreno» y «mundano» dado a los negocios eclesiásticos con este procedimiento, como lo encontramos definido por uno de los detractores del recurso de fuerza ${ }^{223}$, frente a un derecho divino expresión de lo ultraterreno, se refiere al "ajuste" de la potestas iurisdictionis fundamentada en una convergencia legal que excluye la formación de una iurisdictio espiritual sacra formalmente separada del derecho castellano ${ }^{224}$. No se trata de que ésta se haga secular, en el sentido jurídico del término; pero tampoco en el contexto de una supuesta "secularización» de la Iglesia ${ }^{225}$, cuyo significado sólo responde a un concepto usado en una construcción histórica de principios de siglo ${ }^{226}$. De lo que se trata es de que la iurisdictio espiritual adquiere un valor jurídico resultado de la convergencia constitutiva de una legalidad que bebe indistintamente de razones temporales y espirituales - que no hay que confundir con el dogma y la religión-, pero cuya principal razón inductiva

definitiva, data a favore di detto don Hurtado per Monsr. Illmo Patriarca Alessandria Nuntio Apostolico supra l'essecutione di più rescritto Apostolici, dele qualli $V$. Illma. è deputato essecutore Sabato alli 12 di ottobre di $96 "$ " ASV, Fondo Borghese, I, 775, fols. 190r-195r. Sobre este hecho se llama la atención en un discurso citado sobre el recurso de fuerza: «... quanto che pare, che tendano ad allargar la facoltà, che pretendono dette tribunali laici, et far più amplio il camino della consuetudine, che pretendeno di poter conoscer per via di forza in ogni sorte di cosa, non avvertendo quanto le sopradette cose siano contra il Concilio di Trento, sacri canoni et l'istesso honor di Dio", «Abusi, danni, et inconvenienti, che si segueno dal ricorso per via di forza secondo hora si costuma", op. cit. Vid. TuRCHinl, A., op. cit.

223 Según esta valoración, el juez eclesiástico, “...per non poter fàr altro, è forzato à consentire di servir solo per nudo instrumento a fine di dar "una certa ombra che si trattino come negotii ecclesiastici, esssendo la verità, che si fanno cosi secolarmente come tutti gl'altri negotii secolari..." (la cursiva es nuestra), "Abusi, danni, et inconvenienti, che si segueno dal ricorso per via di forza secondo hora si costuma", op. cit.

${ }_{224}$ En manos del Consejo de Castilla queda la facultad de este "ajuste" legal: "...sotto questi pretesti delle leggi et consuetudini di questi Regni il Conseglio procura di tener solo la chiave dell'una et l'altra giurisdittione non lasciando fare essecutione senza intrometttersi nella cognitione delle cause et da la forma alli giudici ecclesiastici come devono sententiare et processare...", [Memorial del Nuncio, Patriarca de Alejandría, para Roma, Cardenale Aldobrandino, enviado con carta de 6 de diciembre de 1597], op. cit.

225 Cfr. Prodi, P., “Introduzione» en, Fisco, religione, Stato nell'età confessionale (eds. $\mathrm{H}$. Kellenbenz y P. Prodi). Bologna, 1989, p. 9.

226 En este sentido, D. Martín ha negado la validez científica del término «secularización", "Negare validità al concetto di sesolarizzazione", La secolarizzazione (eds. S.S. Acquaviva e Gustavo Guizzardi). Bologna, 1973, pp. 187-198. Vid. también, Fester, R., Die Säkularisation der Historie. Congreso Internaciona de historiadores de Berlín, 1908. LüBBE, H., La secolarizzazione. Storia e analisi di un concetto. Bologna, 1970. NiJK, A.J., Secolarizzazione. Brescia, 1973. 
es jurídica ${ }^{227}$. La separación y la división es algo que compete a la ejecución de la auctoritas, no al derecho expresión de una justicia legal sobre cuya base se desenvuelve el diálogo entre rey y súbdito y la correspondiente legitimación de razones inductivas necesaria para la ejecución de la autoridad, incluida la religiosa. Ello es posible porque el «ajuste" legal lleva consigo que la auctoritas espiritual se instituya también mediante la razón, no con los principios sacros como la sagradas escrituras ${ }^{228}$.

Aunque la Nunciatura intentase integrar las causas de religión en una razón, ni vinculada ni sujeta al derecho, como necesidad religiosa preferente en un vínculo de estado ${ }^{229}$, siempre con la intención de dualizar las relaciones entre la monarquía y la Santa Sede, con lo que ello supondría de preeminencia de lo espiritual, la obediencia al pontífice y a la autoridad religiosa, como auctoritas pública, se produce conforme a derecho ${ }^{230}$. Sólo a partir de este vínculo jurídico se articula la relación, por causa espiritual, entre la Santa Sede y la monarquía de Felipe II. Una relación que no es dual, pues se apoya en los fundamentos constitutivos de una relación de servicio entre el «rey natural», como príncipe defensor de agravios, y sus súbditos con arreglo al binomio auxilium et consilium, que se carateriza por su disposición atomizada. El papel desempeñado por el recurso de fuerza es servir, como instrumento y expresión de la voluntariedad e indeterminación de los vínculos medidos en términos de lealtad, de instrumento de aquélla conformidad y como neutralizador de la dualidad.

${ }^{227}$ Se trata de una convergencia jurídica y legal, no de que la jurisdicción ecłesiástica se haga secular y se secularice, según la acepción jurídica de este término. Cfr. HermanN, Ch., op. cit., p. 28. Tambièn, TURRINI, M., "ll giudice della coscienza e la coscienza del giudice», Disciplina dell'anima..., op. cit., p. 294.

228 Vid. Holopainen, T.J., Dialectic and theology in the Elevent Century. Leiden, New York, 1996.

229 Sobre el conflicto surgido sobre el recurso de fuerza, el nuncio, afirma: “...il stato di questo negotio non admette consulta di ragioni civile et d'interpretatione rigorosa delle leggi di Spagna; $\mathrm{Ma}$ che tutto è posto in convenienza di stato et di religione proponendosi avanti gl'occhi il bene della Chiesa Universale et l'unione di questi Regni con la Chiesa Romana, li quali due rispetti in una Republica Cristiana et catolica come questa tengono maggior per et forza che l'osservanza delle leggi et consuetudini particolari in quella parte dove non s'accordano con li decreti della sudetta Chiesa et causano manifesta confusione et ch'perciò se V.Mtà. nella deliberatione che vuol fare per servitio delli suoi stati et successione intenderà il parere di persone prattiche et di scienza et conscienza ben'intentionate et fuori di passione si disponerà a togliere questi imbarazzi mentre Dio le da vita et à publicare questa sua risolutione", [Memorial del Nuncio, Patriarca de Alejandría, para Roma, cardenal Aldobrandino enviado con carta de 6 de diciembre de 1597], op. cit.

230 «Si consta que el prelado manda conforme a derecho, obligacion tiene el subdito de le obedecer, como por el contrario si consta que manda contra derecho, no está obligado a ello... si el subdito duda si esta obligado a obedecer, o le parece que manda contra derecho movido de causas leves, no tiene obligacion de obedecerle, quando de su obediencia se teme mayor peligro, como en ei tratado del orden judicial», M. Rouriguez Lusitano, op. cit., p. 48. 
En último término, el problema debatido sobre la aplicación del recurso de fuerza en la monarquía de Felipe II, era marcar y definir los límites y atributos de lo que no es jurisdiccional, elevándolo al rango de obligación, que competía a la constitución del "reino natural" y como garantía de una legalidad que se instituía alrededor de la figura de un «rey defensor» de sus súbditos naturales. Una figura que debemos añadir como vértice a las de rey justiciero y rey legislador. Ello nos indica la importancia que los medios no judiciales e indeterminados tenían en la constitución de la monarquía; pero ello siempre que se constituyan en razones inductivas en derecho, es decir, en razones jurídicas. En realidad, de estos medios depende la interrelación, en forma de "comunicación", entre los distintos estados y cuerpos y la consiguiente ejecución de la autoridad.

Como consecuencia, las disputas surgidas alrededor del recurso de fuerza denotan un conflicto en el que se debate la soberanía y exención del príncipe temporal, el vínculo natural entre el rey y sus súbditos ${ }^{231} y$, con su intervención, asentar el «reino natural» o la monarquía, en función de principios temporales; pero ello no por relación a lo espiritual, sino con respecto a un orden jurídico natural inmutable. Por tanto, lo que estaba en juego era la conservación y definición del “reino natural", y con él, la supervivencia conceptual, la libertad, y la condición legal de lo temporal, ante las potenciales repercusiones de una iurisdictio de derecho divino o de una obligación moral in spiritualibus, impulsadas con la idea de reformatio y de universalidad. Lo espiritual no podía constituirse en una razón inductiva sacra privativa de la autoridad religiosa susceptible de impulsar una relación dual con el poder temporal, pues ello hubiera obligado a la determinación jurídica de lo espiritual como superioritas. Mientras que, la reformatio no podía constituir alteración del orden judicial de la mano del derecho divino directe ni indirecte. Aquélla también aludía al principio renovaturus mundum que competía a lo temporal natural y que ${ }^{232}$, por virtud del recurso de fuerza, es decir, de la exención, quedaba, directe e indirecte, bajo su sanción o, en su caso, bajo su ejecución.

231 P. López de Montoya de este modo lo describe: "Pero dicono alcuni, che non può mancar d'haver differentie tra Principi, quando per cio che li Rè tengono obbligation di difendere, e proteggere li vassalli, sicome li sommi Pontifici sono obligati a diffendere l'autorittà della Sede Apostolica", op. cit. EI CONDE DE LA CAÑADA hace alusión a la soberanía como causa del recurso de fuerza, pues, el rey se encuentra obligado «... á que se interponga su natural defensa alzando y quitando la fuerza que causan á sus vasallos; demostrándose por estos principios, que no sólo se interesa aquí el oficio de la protección real en general para con los cánones, y en particular para con el Santo Concilio de Trento, sino principalmente el de la Soberanía en defensa del Estado», op. cit., p. 314.

232 CONTAMine, Ph.,"Le vocabulaire politique en France à la fin du Moyen Age: L'idée de réformation", op. cit., pp. 145-156, 


\section{CONCLUSIÓN}

En el conflicto suscitado con motivo del recurso de fuerza entre la Santa Sede y la monarquía de Felipe II, se anula la consideración de una dualidad, espiritual y temporal, de las relaciones entre la Iglesia y la monarquia, o entre la monarquia y el estado eclesiástico. Dichas relaciones no pueden ser deslindadas de su vertebración y vínculos jurídicos. Una vertebración que no sólo no se apoya en la dualidad, sino que su función es impedir la dualización en el "reino natural» y en lo universal. De esta forma, lo que tradicionalmente se ha venido considerando como alianza entre el trono y el altar para caracterizar las relaciones entre el poder espiritual y el temporal en la Edad Moderna, no solamente no se produjo, sino que se actuó para que no se produjera; la exención en lo temporal lo impedía. La unitas estructural no se desenvuelve alrededor de una comunicación entre la Iglesia y el poder temporal ${ }^{233}$, pues ambos se insertan en un entramado en el que los vínculos y las relaciones se establecen dentro de un orden jurídico que se fundamenta en la división de la autoridad, con independencia de su especie. El hecho de que el poder absoluto deslegitimase la autoridad, concepto que se plasma en la crítica que hace la Nunciatura al excesivo dominio de los prelados, señala a la Santa Sede como defensor de esta división; pero también a Felipe II ${ }^{234}$. Incluso se puede llegar a utilizar el término absoluto como sinónimo de libertad jurisdiccional, es decir, de exención, para el poder temporal, siendo esta acepción la que tiene viabilidad pública ${ }^{235}$. En cualquier caso, la potestas omnimoda y absoluta, o su transformación en potentia, era jurídicamente inviable $y$, en esta segunda mitad del siglo xVI, conceptualmente ilegítima.

La división de la autoridad y de la potestas se llevaba a la práctica, entre otros instrumentos, por la parte pontificia, con la immunitas ${ }^{236}$, pues

233 Cfr. SCHILling, M., op. cit., pp. 208-209.

${ }^{234}$ Vid. CONDE DE ATARES, op. cit. El propio Felipe II así se lo enseña a su hijo: “El consejo en asuntos de Estado son prueba de que su Príncipe no distruta de autoridad absoluta", p. 664.

235 «Et primo circa lo quart. cap. de dita Bulla (In coena Domini) par que per aquella se vulla limitar y cohartar la libera y absoluta Juirisdictio y facultatte sa magestad en sos regnes circa sos vasalls in pedagiis gabellis imponendis...", Memorial de les coses se han de consultar ab sa magestad y sou sacro suppremo real consell circa de lo contingunt en la bulla in coena domini noviter publicada en algunas ciutats del present regne de Serdenya de la date en Roma vi kalendas aprilis 1567 en, M. CANEPA, M., "La Bolla "In Coena Domini" del 1567 in un memoriale del Vicerè Spagnolo di Sardegna", Archivio Storico Sardo, Padova (1964), p. 134.

236 En una instrucción dada al nuncio de Madrid, se establece esta correspondencia al afirmarse que los obispos de España pretenden "...il Dominio assoluto, et quasi una signoria sopra li capitoli et clero delle loro chiese", "Istruttione d'alcune cose di Spagna in materia di giurisoizione per il Nuntio di Spagna», 1591, ASV, Misc. Arm. 1-XV, Arm. I, vol. 89, tol. 55r-61v. 
con ella se activa la auctoritas del clero, con el mismo rango que otras autoridades; mientras que, por la parte real, con el recurso de fuerza, al obligar al estado eclesiástico con respecto al "rey natural», y activar por este lado la división de la potestas y de la auctoritas, en sus diferentes formas o cuerpos, en una relación de servicio. Por consiguiente, debido a que aquella auctoritas no se basaba en una dualidad jurisdiccional -pues jurisdicción real y jurisdicción eclesiástica se integran en este orden-, es la división y no el jurisdiccionalismo, la que explica el hecho sobre el que Prodi llamó la atención al señalar que la intervención de este último anulaba la dualidad en las relaciones entre la monarquía y la Santa Sede ${ }^{237}$. Esto quiere decir que una supuesta concordia entre el poder espiritual y el poder temporal no será constitutiva de una autoridad más efectiva, pues ello, con el principio de superioridad del poder espiritual, hubiera dejado a los príncipes católicos en manos de la legitimación pontificia ${ }^{238}$.

La unitas de razones filosófico teológicas emanadas del Concilio de Trento ${ }^{239}$, en la que se apoya la dualidad conceptual de lo temporal y de lo espiritual, no se pone al servicio de la autoridad, religiosa y secular, sino de vínculos jurídicos. Gracias a esta unitas de razones, que no de conceptos, la dualidad puede ser asumida por todos los estados y cuerpos a través de sus respectivos vínculos y obligaciones, en lo temporal y en lo espiritual, con respecto a lo natural y al pastor universal. Ello lo vemos reflejado en el hecho de que la immunitas encontrase su sanción por medio de un Consejo cristiano y secular, como el Consejo de Castilla. Gracias al recurso de fuerza el clero se agrega a este orden también en lo temporal, impidiéndose la separación de la autoridad espiritual en beneficio de lo sagrado, lo que hubiera podido ser efectivo mediante una immunitas por razón temporal. La obligación del clero con respecto a lo temporal responde a una legalidad cuyo principio fundamental es impedir la iniunctio de la potestas, lo que, por la parte pontificia, respondería al principio jurídico de plenitudo potestatis papal. Frente a la eventualidad de una conjunción entre ésta y la conditio sagrada del clero, con la intervención del derecho divino, y con la consiguiente constitución de un precepto y de una ratio espiritual de rango superior al temporal, gracias a la intervención del recurso de fuerza se obtiene la exención por un lado, y la contravención de la autoridad espiritual, por otro, equiparándola en este caso con la autoridad

\footnotetext{
237 “San Carlo Borromeo...", op. cit., p. 235. Cfr. VISMARA, P., op. cit., p. 260.

238 Como el propio Felipe il señaló, pues los papas, "amigos, dan autoridad a las acciones de los Príncipes; enemigos, se la quitan", CONDE DE ATARES, op. cif., p. 661.

239 PuLLAPILLY, C.K., “Agostino Valier and the conceptual basis of the Catholic Reformation", HTR, 85, 3 (1992), pp. 307-333.
} 
secular. Y ello según los principios constitutivos del "reino natural». Se impide la constitución de una ejecución espiritual o sacra, pues, merced a aquella unitas de razones, la ratio espiritual sirve indistintamente a necesidades temporales y religiosas. Por lo que, a pesar de los esfuerzos desplegados por los pontífices en el periodo tridentino y postridentino por dualizar las relaciones entre la monarquía y el papado por razón moral y religiosa, con el intento de impedir la independencia del poder temporal, la exención, que es efectiva con la emergencia de un "rey católico» temporal, lo impide. Al no ser viable la dualización, la autoridad religiosa termina por no desligarse de las fuentes de las que bebe la temporal: la lealtad, la obediencia, la costumbre, el consilium, el privilegio, la norma jurídica y legal, la convergencia legal, la contravención, la aprobación, la división de la autoridad, es decir: la plenitudo quaedam iuris. Lo espiritual no se constituia en absoluto, pero tampoco lo temporal. En este contexto, el monarca emerge en su doble faceta temporal y espiritual, pero como "rey natural», soberano, "rey católico", "príncipe cristiano», como patrón y protector. Principios todos que tiene un significado jurídico y conceptual diverso, y preciso ${ }^{240}$, en función de los cuales se establecen los vínculos pertinentes, y se dispone la relación entre rey y súbdito secular o religioso, rey y clero, $y$, por tanto, rey, clero y pontífice, que responden a una lógica legal nuclear específica, y cuya interrelación dividida impide la constitución polar de las potestades de Dios y del César, pero también la complicidad de una cohabitación in spiritualibus en el orden legal.

240 Cfr. LavagGi, A., "Los recursos de fuerza. Su extinción en el derecho argentino", Rev. de Historia del Derecho, 5 (1977), p. 75. 